\title{
EFFECTS OF RETARDING ADMIXTURES ON PLASTIC SHRINKAGE OF PORTLAND CEMENT PASTE
}

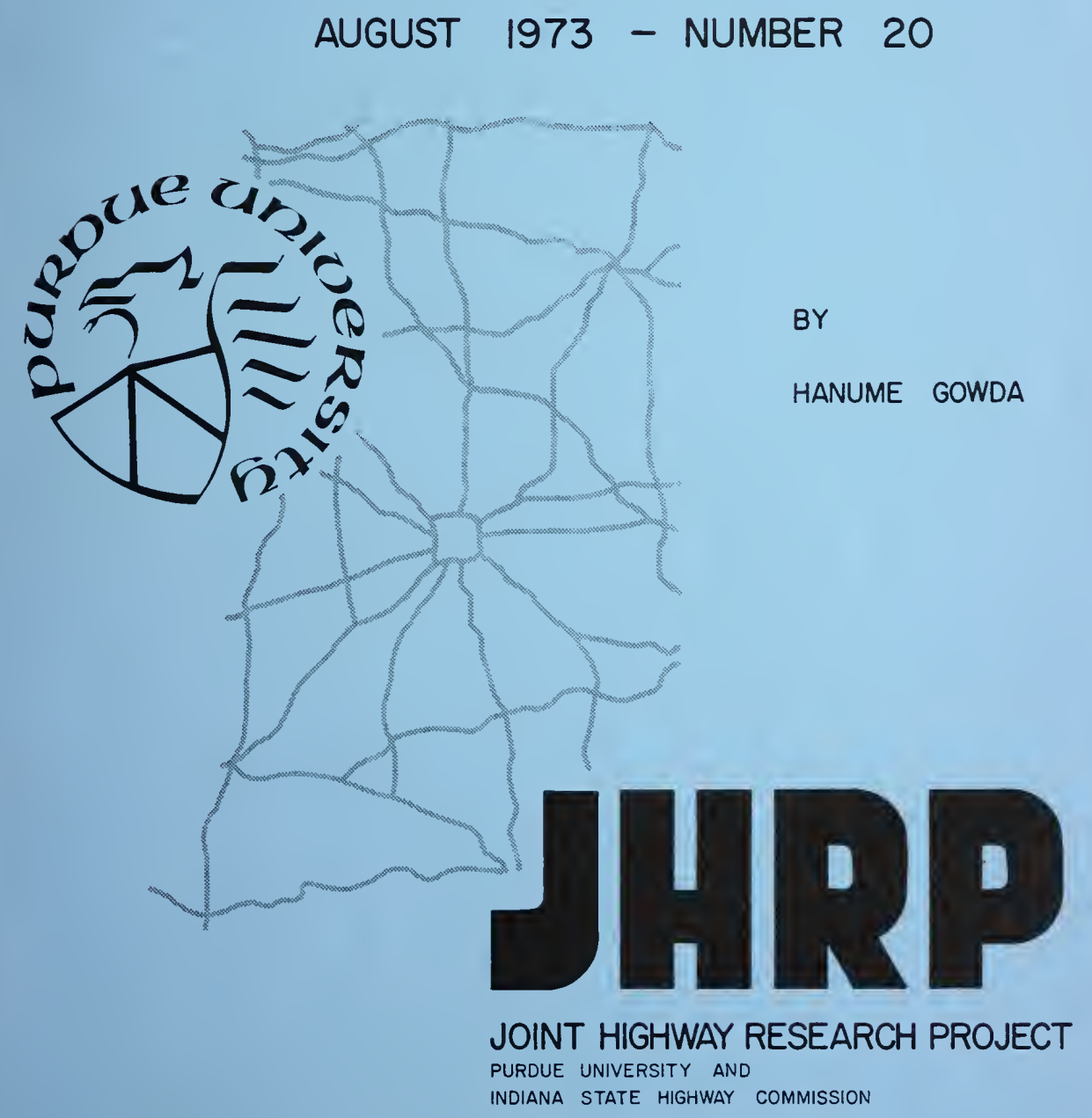





\section{Interim Report}

\section{EFFECTS OF RETARDING ADMIXTURES ON PLASTIC SHRINKAGE OF PORTLAND CEMENT PASTE}

TO: J. F. McLaughilin, Director Joint Highway Research Project

FROM: H. L. Michael, Associate Ofrector Joint Highway Research Project
August 29, 1973

Project: C-36-47L

File: $\quad 5-6-12$

The attached Interfm Report covers a portion of the work performed on the HPR Part II Research Study tItled "Effect of Retarders on Volume Changes in Portland Cement". This Report titled "Effects of Retarding Admixtures on Plastic Shrinkage of Portland Cement Paste", has been authored by Hanume Gowda under the direction of Professor C. F. Scholer.

The Report describes the effects of retarding admixtures, ASTM Type 0 , on plasttc shrinkage of portland cement paste. The results indicate that plastic shrinkage, when using retarding admixtures, are higher than plastic shrinkage of platn paste. Evidence indicates that plastic shrinkage is influenced by the rate of evaporation, hydration and microstructure of the paste.

The Interim Report is submitted as partial fulfillment of the objectives of the Study and for review and comment of the sponsors, the Indlana State Highway Commisston and the Federal Highway Administration.

Respectfully submitted,

$H L M: m s$

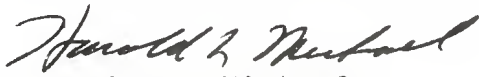

Harold L. Michael

Assoclate Director $c c$ :
R. H. Harrell

M. L. Hayes

C. W. Lovel1

G. W. Marks

R. D. Miles

G. T. Satterly
C. F. Scholer

M. B. Scott

J. A. Spooner

N. W. Steinkamp

H. R. J. Walsh

E. J. Yoder 
TECHNICAL REPORT STANDARD TITLE PAGE

\begin{tabular}{|c|c|}
\hline 2. Government Aceession No. & 3. Reciplent's Cotalog No. \\
\hline \multirow{2}{*}{$\begin{array}{l}\text { 4. Tile and Subtile } \\
\text { EFFECTS OF RETARDING ADMIXTURES ON PLASTIC } \\
\text { SHRINKAGE OF PORTLAND CEMENT PASTE }\end{array}$} & 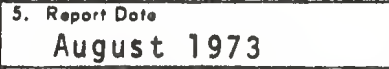 \\
\hline & $\begin{array}{l}\text { 6. Performing Orgonlization Codo } \\
\text { C- }-36-47 \mathrm{~L}\end{array}$ \\
\hline $\begin{array}{l}\text { 7. Author(s) } \\
\text { Hanume Gowda }\end{array}$ & $\begin{array}{l}\text { 8. Performing Orgonization Roport No. } \\
\text { JHRP }-20-73\end{array}$ \\
\hline \multirow{3}{*}{$\begin{array}{l}\text { 9. Porforming Organizotion Nome and Addro. } \\
\text { Joint Highway Research Project } \\
\text { Civil Engineering Building } \\
\text { Purdue University } \\
\text { West Lafayette, Indiana } 47907\end{array}$} & 10. Work Unit No. \\
\hline & $\begin{array}{l}\text { 11. Controct or Gront No. } \\
\text { HPR-1 (11) Part I I }\end{array}$ \\
\hline & 13. Type of Report and Period Covered \\
\hline \multirow{2}{*}{$\begin{array}{l}\text { 12. Sponsoring Agoney Nome ond Addros } \\
\text { Indiana State Highway Commisston } \\
100 \text { North Senate Avenue } \\
\text { Indianapolis, Indlana } 46204\end{array}$} & Interim Report \\
\hline & $\begin{array}{l}\text { 14. Sponsoring Agency Codo } \\
\text { CA } 369\end{array}$ \\
\hline
\end{tabular}

15. Supplementory Notee

Conducted in cooperation with the U.S. Department of Transportation, Federal Highway Administration. Research Study titled "Effect of Retarders on Volume Changes in Portland Cement Concrete".

16. Abstroct

This paper describes the effects of water reducing and retarding admixtures, ASTM Type D, on plastic shrinkage of portland cement paste under different controlled relative humidities. Three types of commerclal admixtures were used each representing a different common chemical classification of such retarders. Concentration of each retarder was that which gave fifty percent retardation of a 0.50 water cement ratlo mortar by penetration resistance. The length change measurements were made on thin cement paste sections floating on mercury. A magnetic proximeter was used to measure the length changes.

The results of this work indicate that plastic shrinkages, when using retarding admixtures, are higher compared with the plastic shrinkage of plain paste. The higher shrinkage is due to the increased time in the plastic stage of paste and possible changes in paste microstructure evidenced by bleeding characteristics with some retarders. The appearance of plastic shrinkage cracks occurred during the transition from a high measured rate of shrinkage to a subsequent lower one. Evidence indicates that plastlc shrinkage is influenced by the rate of evaporation, hydration and microstru ture of the paste.

\section{Koy Words \\ Portland Cement Concrete, Cement Paste, Plastic Shrinkage, Plastic Drying Shrinkage, Ad- mixtures}




$$
\text { Interim Report }
$$

EFFECTS OF RETARDING ADMIXTURES ON PLASTIC SHRINKAGE OF PORTLAND CEMENT PASTE

\author{
by
}

$$
\begin{aligned}
& \text { Hanume Gowda } \\
& \text { Graduate Assistant in Research }
\end{aligned}
$$

$$
\begin{aligned}
& \text { Jolnt Highway Research Project } \\
& \text { Project No.: } \quad \text { }-36-47 \mathrm{~L} \\
& \text { Flle No.: } \quad 5-6-12 \\
& \text { Conducted by Purdue University } \\
& \text { In Cooperation With The } \\
& \text { Indiana State Highway Commission }
\end{aligned}
$$

Purdue University West Lafayette, Indiana

August 29, 1973 


\section{ACKNOWLEDGEMENTS}

The author is deeply grateful to Dr. C. F. Scholer, his major professor, for his kind guidance and encouragement during the course of this work. The help and valuable suggestions of $\mathrm{Dr}$. W. L. Dolch and Dr. S. Dfamond are most appreclated. Appreclation is also extended to Professor M. J. Gutzwiller.

The discussions with Mr. D. L. Gress and B. D. Barnes were helpful and meaningful in solving many difficulties.

Th1s research was sponsored by the Indiana State Highway Commission and the Federal Highway Administration through the Purdue University Joint Highway Research Profect. The author wishes to thank these organizations for their support of this work. 
Digitized by the Internet Archive in 2011 with funding from

LYRASIS members and Sloan Foundation; Indiana Department of Transportation 
TABLE OF CONTENTS

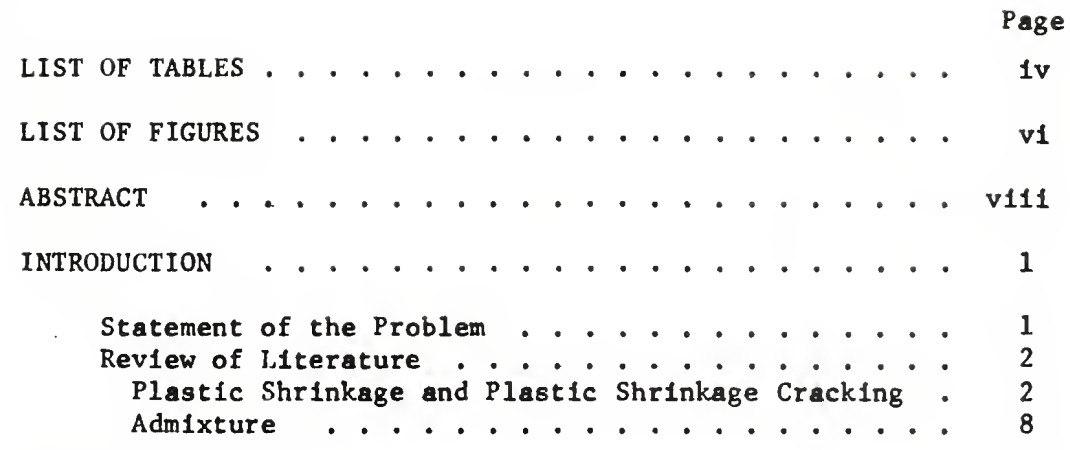

EXPERIMENTAL WORK . . . . . . . . . . . 12

Materials ................. 12

Retarding Admixtures ........... 12

Cement. . . . . . . . . . . . . 12

Water . . . . . . . ...... 16

Apparatus and Equipment . . . . . . . . . 16

Procedure ................. 23

Mixing the Cement Paste............ 23

Preparation of Specimen........... 23

Measurement of Plastic Shrinkage . . . . . . . 24

RESULTS .................. . . 27

Vicat Setting Times............ 27

Plastic Shrinkage ............... 27

Analysis of Varlance . . . . . . . . . . 44

DISCUSSION $\quad 54$

Plast1c Shrinkage ............. 54

Plast1c Shrinkage Cracking .. . . . . . . . 59

CONCLUSIONS . . . . . . . . . . . . . . . 64

LIST OF REFERENCES . . . . . . . . . . . . 65

APPENDIX ...................... 67 
1. Retarding Admixtures . . . . . . . . . . 13

2. Chemical Properties of Cement Lab. No. 319-1 . . . 14

3. Phyolcal Properties of Cement, Lab. No. 319-1 . . 15

4. Calibration of Syatron Donner Voltmeter ...... 21

5. V1cat Setting Times for Pastes.......... 28

6. Shrinkage for Plain Paste at 25 Percent Relative Humldity .............. 29

7. Shrinkage Uaing Lignosulfonate at 25 Percent Relative Hunidity ........... 30

8. Shrinkage Using Carbohydrate at 25 Percent Relative Humidity .............. 31

9. Shrinkage Uaing Hydroxycarboxy1ic Ac1d at 25 Percent Relative Hunidity ............ 32

10. Shrinkage for Plain Paste at 50 Percent Relative Hum1d1ty ............... 33

11. Shrinkage Using Lignosulfonate at 50 Percent Relative Humidity ........... 34

12. Shrinkage Using Carbohydrate at 50 Percent Relative Humfdity ............. . . 35

13. Shrinkage Using Hydroxycarboxyl1c Actd at 50 Percent Relative Humidity ........... 36

14. Shrinkage for Plain Paste at 75 Percent Relative Hunidity . . . . . . . . . . 37

15. Shrinkage Using Lignosulfonate at 75 Percent Relative Hunid1ty ........... 38

16. Shr1nkage Using Carbohydrate at 75 Percent Relative Humidtty ........... 39 
LIST OF TABLES, cont.

17. Shrinkage Us1ng Hydroxycarboxyl1c Ac1d at 75 Percent Relat1ve Humldity . . . . . . . . . . . .

18. Equ1librium Shrinkages ............ 49

19. F-Rat los for Linear Shrinkages ......... 50

20. Slopes in the Stralght Line Portion ........ 52

21. F-Ratlos for Slopes ............ 53

Append1x

Tables

22. Comparison of Shrlnkages at $25 \%$ R.H. . . . . . 70

23. Comparison of Shrinkages at 50\% R.H. . . . . . 71

24. Comparison of Shrinkages at $75 \%$ R.H. . . . . . . 72

25. Shrinkages for Plaln Paste.......... 73

26. Shrinkages Using Lignosulfonate . . . . . . . 74

27. Shrinkages Using Carbohydrate .......... 75

28. Shrinkages Us1ng Hydroxycarboxyl1c Ac1d ..... 76

29. Comparison of Slopes at $25 \%$ R.H. . . . . . . . 77

30. Comparison of slopes at $50 \%$ R.H. . . . . . . . 78

31. Comparison of slopes at $75 \%$ R.H. . . . . . . 79

32. Slopes for Pla1n Paste ........... 80

33. Slopes Using LIgnosulfonate ............ 81

34. Slopes Using Carbohydrate ........... 82

35. Slopes Using Hydroxycarboxyl1c Ac1d ........ 83

36. Nonevaporable Water Determ1nation . . . . . . 84 37. Shrinkage of Plain Paste by Passing Laboratory A1r
Directly over the Specimen............. 85 


\section{LIST OF FIGURES}

F1gure

Page

1. Experimental Set Up for Shrinkage Measurement . . 17

2. Sample Chamber ............ 17

3. Top Vlew of Sample Chamber . . . . . . . 19

4. Calibration Set Up ................ 19

5. Calibration of Systron Donner Voltmeter..... . 22

6. Vapor Trap Bottles with Sulfuric Actd Solution . . 25

7. Arrangement of Probe and Steel Target when Measuring length Change ........... 25

8. Comparison of Shrinkages at $25 \%$ Relative Humidity . 41

9. Comparison of Shrinkages at $50 \%$ Relative Humidity . 42

10. Comparison of Shrinkages at 75\% Relative Humldity . 43

11. Shrinkage Curves for Plain Paste . . . . . . 45

12. Shrinkage Curves Using (L), Lignosulfonate . . . 46

13. Shrinkage Curves Using (S), Carbohydrate ... . 47

14. Shrinkage Curves Using (A), Hydroxycarboxylic Acid. 48

15. Comparison of Specimens at $25 \%$ R.H. . . . . . 62

16. Comparison of Specimens at 50\% R.H. . . . . . 63

Figures in

Append $1 x$

17. Comparison of Specimens at Laboratory Condition . . 67

18. Shrinkage Curves Using Calclum Chloride...... 68

19. Comparison of Shrinkages at Laboratory Atmosphere - 69 
ABSTRACT

Gowda, Hanume. M.S.C.E. Purdue University, August 1973. Effects of Retarding Admixtures on Plastic Shrinkage of Portland Cement Paste. Major Professor: C. F. Scholer

This paper describes the effects of retarding admixtures, ASTM Type D, on plastic shrinkage of portland cement paste. The length change measurements were made on a thin cement paste sections floatIng on the mercury. A magnetic proximeter was used to measure the length changes. In this work, the three types of commercial retardIng admixtures that are chemically classified in the three principal categories were used. Concentration of each retarder was selected in such a way that it gave fifty percent of additional retardation compared with a control mortar by penetration resistance test. The water cement ratio used in the penetration resistance test on mortar was 0.50 . In length change measurements of paste, a water cement ratio of 0.35 was used. The experiments were conducted at 25,50 and 75 percent controlled relative humidities.

The plastic shrinkages of cement pastes with retarding admixtures were compared with the plastic shrinkage of plain paste. The appearance and amount of plastic shrinkage cracks were also compared.

The results of this work indicate that plastic shrinkages, when using retarding admixtures, are higher compared with the plastic shrinkage of plain paste. The higher shrinkage is due to the increased time 
In the plastic stage of paste and possible changes in paste microstructure evidenced by bleeding characterlstics with some retarders. The appearance of plast1c shrinkage cracks occurred during the transition from a high measured rate of shrlnkage to a subsequent lower one. Evidence Indicates that plastic shrinkage is influenced by the rate of evaporation, hydration and m1crostructure of the paste. 
INTRODUCTION

Statement of the Problem

The Indiana State Highway Standard Specifications, presently specifles the use of water-reducing retarding admlxture as follows:

"Concrete used in the superstructure in structural steel and prestressed concrete spans shall contaln a water-reducing retarding admixture when the superstructure contalns members which are continuous over one or more plers or 1 if 1 appears that the a1r or concrete temperature may exceed $70^{\circ} \mathrm{F}$. during the pouring and finishing operations."

Many properties of concrete are influenced in beneficlal ways by the use of water-reducling retarding admixtures; however, greater plastic drying shrinkage may occur due to the increased length of time during which the concrete is in a plastic condition. When the concrete 18 restrained by foundations, steel relnforcements, etc. and with any volume change, stresses will develop that may rupture the concrete forming cracks. Tensile stress due to shrinkage is critical because the tensile strength of such young concrete is negligible. Plastic shrinkage of concrete is influenced by the rate of evaporation and presumably the response of cement paste to the evaporation as $1 t$ undergoes hydration. Plastic shrinkage of neat cement paste is an indicator of the behavior of concrete containing such a paste (2). The purpose of the proposed work is to determine the effects of retarders on plastic shrinkage of cement paste. Commercial admixtures, acceptable for use by Indlana State Highway Commission as water 
reducing, retarding admixtures, conforming to ASTM C 494 type D speciflcations were considered (3). Three admlxtures were selected which represented each of the three chemical classifications commonly found in comercial retarders:

1. 11gnosulfon1c ac1ds and the1r salts,

2. hydroxycarboxyl1c actds and their salts,

3. carbohydrates (sugars).

\section{Review of Literature}

Plast1c Shr1nkage and Plast1c Shrinkage Cracking

"Volume decrease caused by drying and chemical changes"

which occurs after placement of the concrete and prlor to attaining any signiflcant strength 18 defined as plastic shrinkage. Lerch (4), explained the formation of plastic shrinkage cracks as follows:

"The disappearance of the sheen from the surface of the concrete Indicates the time when the rate of evaporation exceeds the rate at which bleeding water rlaes to the surface. The time required to attain thia condition w11l be influenced by the temperature, relative humidity, and wind velocity of the alr and the temperature and bleeding characteristics of the concrete. At this atage the surface of the concrete has attained some initial rigidity; It cannot accommodate the rapld volume change of plastlc shrinkage by plastic flow, and it has not developed sufficlent strength to withstand tensile stress. Thus plast1c shrinkage cracks may develop".

Plastic shrinkage is not objectionable unless it 18 accompanied by plast1c shrinkage cracking (4). Usually the plastic shrinkage cracks are almost stralght and do not have any definfte symetry or pattern; occasionally they have been observed in a crow-foot pattern. 
They can be easily distinguished from other types of cracks by their depth and lack of pattern.

Plastic shrinkage cracks are not usually progressive (4). They develop prior to the time concrete hardens and they retain thelr or Iginal shape. However, the cracks Increase in number and become wider after their inftial appearance and before concrete hardens (5).

Plastic shrinkage cracks usually have conslderable depth $(4,5)$. In pavement slabs, Lerch (4) found that the cracks have a depth of 4 inches. Sometimes the cracks w1ll extend through the floor slab as well. Ravina and Shalon (5) observed that the cracks extending 811 the way through floor slabs can have a depth of 9 Inches. They also measured the length and width of plastic shrinkage cracks of mortar exposed to different climatic conditions. The length varled from a few Inches to a few feet and width varled from 0.004 Inch to 0.12 inch.

To measure the shrinkage of cement paste, soon fter mixing cement with water, Spindel (6) tried two different methods. The first one, Involved placing the cement paste into a small gless bottle and closing with watertight stopper. A cap1llary tube contalning a short thread of colored liquid was inserted. The observed movement of the colored 11quid showed the shrinkage of the cement paste. The second method consisted of measuring microscopically the distance between two points, Inftielly 100 mm apart, fixed In a cement paste or mortar specimen. 
From results of the above two experimental methods, Spindel (6) observed two critical points when shrinkage takes place; one near the Inftial setting time, and the other at the final setting time.

He also observed that the shrinkage measured during setting was often greater than that which occurred 24 or 48 hours after adding the water (according to the method ASTM C 157). Finally he concluded that the shrinkage during setting 18 most important.

Lerch (4) assumed that the rate of evaporation 18 the most Important factor Influancing plast1c shrinkage and plastic shrinkage crack1ng. He also attributed the effects of temperature of alr and concrete, relative humldity and wind velocity on the rate of evaporation. However, fleld Investigation has shown that the bleeding characteristics of concrate do not have sny major influence on plast1c shrinkage and plastic shrinkage cracking. Attempts have been made to increase the bleeding rate of concrete by Increasing the weter cement rat1o or by using different cements or aggregates, to eliminate plastic shrinkage cracking. These changes in the characterlstics of concrete have not influenced plastic shrinkage and plastic shrinkage cracking.

Since the rate of evaporation from the surface 18 the most 1mportant factor for plast1c shrinkage and plastic shrinkage crack1ng, precautions can be taken to mintmize such shrinksge and shrinkage cracking. A slight change in atmospheric condition can produce a 
considerable change in amount of plastic shrinkage and thereby in the extent of formation of plastic shrinkage cracks. Revine and Shalon (5) measured the plastic shrinkage of mortar prisms starting from one hour after the beginning of mixing. They conducted tests on specimens of different mix proportions and exposed to different climatic conditions. The measured shrinkage values vary from 4000 to 11,000 m11110nths. Further, they measured evaporation of spec1mens exposed to different climatic conditlons and found that values varled from 0.6 to $2.05 \mathrm{~kg} / \mathrm{m}^{2} /$ hour.

Slate and Matheus (7) measured the autogeneous volume change of cement paste and concrete starting from 15 minutes up to seven days after the addition of water. The volume change at seven days varted from 0.6 to 1.7 percent, with a decreasing rate of change throughout the perlod. In the case of cement paste, expansion was recorded up to 6 hours, followed by contraction.

The aurogeneous volume changes measured by Slate and Matheus (7), closely agree with the results of del Campo (8). There is a difference between the results of the two studies; the Initlal expansion followed by contraction shown by Slate's and Matheu's results were not shown by del Campo's result. Slate and Matheus have not offered any explanation for this. According to Beresford and Blakey (10), plastic shrinkage or prehardening cracks depend on differential settlement, rather than 
on the magnitude or rate of bleeding. They also observed the phenomena of cracking within a few minutes of placement of concrete. In the case of fast bleeding, the cracks forming early, may disappear about the time the water leaves the surface, and reopen sometimes with subsequent rapld drying. When bleeding is long and slow, the early cracks are sharp and have 1 ess tendency to progress. Beresford and Blakey observed that the cracks resulting from rapid bleeding closed off eas1ly at the top with delayed working of the concrete surface, and reopened if subsequent drying was rapld. The cracks always occur over relnforcement and over large pleces of agregate or simflar obstructions to settlement.

Tuth111 (11) reported that plast1c shrinkage cracks occurred on the surface of concrete footings even if the concrete was flooded with water immediately after placement. In his opinion, this type of cracking was not due to excessive drylng. He also suggested that the false set due to very low $\mathrm{SO}_{3}$ content and other characteristics of cement may influence plastic shrinkage cracking.

Ravina and Shalon's (5) test results supported the fact that rapid evaporation has a predominent effect on plastlc shrinkage cracking. Further, they observed that the appearance of plastic shrinkage cracks were conslatently colncldent with the transition from rap1d volume change to the slow volume change. They suggested that this transition 1s due to changes in the flow properties of the mortar which in turn depend on the rate of hydration and to a lesser extent on evaporation. According to their test results no 
correlation was found between the bleeding water and plastic shrinkage cracking. From the above discussion they concluded that plastic shrinkage cracking is not a direct function of shrinkage, water loss or evaporation rate. Also, they suggested that delayed stiffening of mortar by using slow setting cement or retarders, 1ncreases cracking when mortar is exposed to hlgh evaporation due to the reduction of strength of mortar which 18 lower than the stress level caused by plastic shrinkage.

While discussing Lerch's paper Abdun-Nur (9) recommended the use of a water reducing retarding admixture to minimize plastic shrinkage cracking for the following reasons:

1. It delays the setting time, thereby keeping concrete in the plastic stage for longer perfod. Th1s alds it to sfust to volume changes due to drying, without developing cracks.

2. It keeps the rate of bleeding water greater than the rate of evaporation, thereby minimizing plastic shrinkage cracking.

3. It lowers the water cement rat1o, which in turn decreases the potential volume change due to drying and therefore the potential shrinkage cracking.

Another advantage of using retarder is the gain in strength through lowered water cement rat 1o which results in improving the durab1lity of concrete. 
Abdun-Nur gave reasons to use water reducling retarding admixture, assuming that the rate of evaporation is the main predominent factor while causing plastic shrinkage cracking. But, he did not consider the effect of water reducing retarding admixture on the plastic shrinkage with the longer perlod of plastic stage of concrete. Hence, he was in disagreement with the findings previously discussed.

It seems that there are two schools of thought regarding the definition of plastic shrinkage and plastic shrinkage cracking, represented by Lerch on the one hand, and by Blakey, Beresford and Matt1son on the other.

Lerch (4) concluded from his fleld studles that "if the rate of evaporation exceeds the rate at which bleeding water rises to the surface, then the plastic shrinkage and plestic shrinkage cracking are likely to occur." Blakey, Beresford and Mattison considered that the prime cause of the cracking is the settlement of the fresh concrete. While analyzing the above studles, Ravina and Shalon (5), concluded that the plastic shrinkage cracks are the result of tensile stresses caused by shrinkage, and presetting cracks are the result of shear stresses caused by settlement. According to the above distinction, the present paper deals with plastic shrinkage and plastic shrinkage cracking only.

\section{Admixtures}

An admixture is defined as material other than water, aggregates, and portland cement that is used 8 an ingredient of concrate and is 
added to the batch immediately before or during 1 ts mixing. Additives are distingulahed from admixtures as materials which are interground or interblended with portland cement during preparation rather than during mixing (12).

An admixture 18 used to modify the propertles of concrete so that 1t 18 more sultable for the work at hand. The desired objectives may be achleved by changes in composition or proportlone of thesconcrete m1x rather than by the use of an admixture. Admixtures are no substitute for good concreting practices, but in certain instances, the desired objectives can be achleved economically by using suftable admixtures. Any admixture that is used should be employed only after appropriate evaluation of 1 ts effects with the particular concrete and under conditions of use intended. In considering the effects of admixtures on concrete it is pointed out by ACI Committee 212, Admixtures, (13) that:

1. A change in type of cement, amount of cement used, mod1fication of agregate, grading of $\mathrm{mIx}$ proportions may be desirable.

2. Many admixtures affect more than one property of concrete, sometimes affecting desirable properties adversily.

3. The effects of some admixtures are significantly modified by such factors $a$ wetness and richness of the $\mathrm{mlx}$, by aggregate grading and by character and length of mixing.

4. The specific effects of some admixtures vary with the type, quantity and propertles of cement used. 
5. Accordingly, some specific effects of an admixture usually can not be predicted accurately prtor to testing. ASTM designation C 494-71 defines type B and type D chemical adm1xtures as follows (3):

Type B- Retarding admixture: An admixture that retards the setting of concrete.

Type D- Water reducing and retarding admixtures: An admixture that reduces the quantity of mixing water required to produce concrete of alven consistency and retards the setting of concrete.

According to ASTM specification C 494 chemical admixtures meeting the requirements of type $D$ w1Il also meet the requirements for type $B$ admixtures. Admixtures that are avallable for use ss water reducing and set retarding concrete may be classifled as follows:

1. Lignosulfonic ac1ds and their salts.

2. Modifications and derivatives of $11 \mathrm{gnosulfon} 1 \mathrm{c}$ acids and their salts.

3. Hydroxylated carboxylic acids and their salts.

4. Modifications and derivatives of hydroxylated carboxylic acids and their salts.

5. Carbohydrates and modifications and derivatives thereof.

Classes 1 and 3 admixtures can be used elther alone or in comb1nation with other substances. They are water reducing and set retarding admixtures. Further, class 1 admixtures, 11gnosulfonic acids, entrain 2 to 6 percent air in the concrete, but class 3 admixtures, 
hydroxylated carboxylic acid salts, act water reducing, non-air entraining retarders.

Classes 2 and 4 are water reducing admixtures offered as combinations of substances designed to have varying degrees of acceleration or retardation in the rate of hardening of concrete.

Class 5 admixtures causes retardation of setting of portland cement and concrete when used alone. Many carbohydrates must be used with caution because widely varying retardation can be obtained with relatively sma11 changes in proportions. 
EXPERIMENTAL WORK

\section{Materials}

\section{Retarding Adm1xtures}

Three admixtures representing each of the three chemical classiflcations commonly found in commerclal retarders were used:

1. 11gnosulfonic acids and their salts,

2. hydroxycarboxyl1c actds and their salts,

3. carbohydrates (sugar).

The concentrations of the three commerclal retarding admixtures required for fifty percent retardation are determined by the penetration resistance test (ASTM C 403-70) on mortar with water cement rat1o 0.50 by welght, concentration was expressed as weight percentage of the retardation $8011 \mathrm{ds}$ based on the cement. Th1s experimental work was carried out by Y. Yamamoto and detalls can be found in reference (17). Density, amount of solid content, and volume of solution required for $100 \mathrm{~g}$ of cement of each commerclal retarder are shown in table 1.

\section{Cement}

The physical and chemical properties of the cement used are given in tables 2 and 3 . The cement from a single mill grind was ASTM type I, Lab. No. 319-1. The cement, selected from one sack 


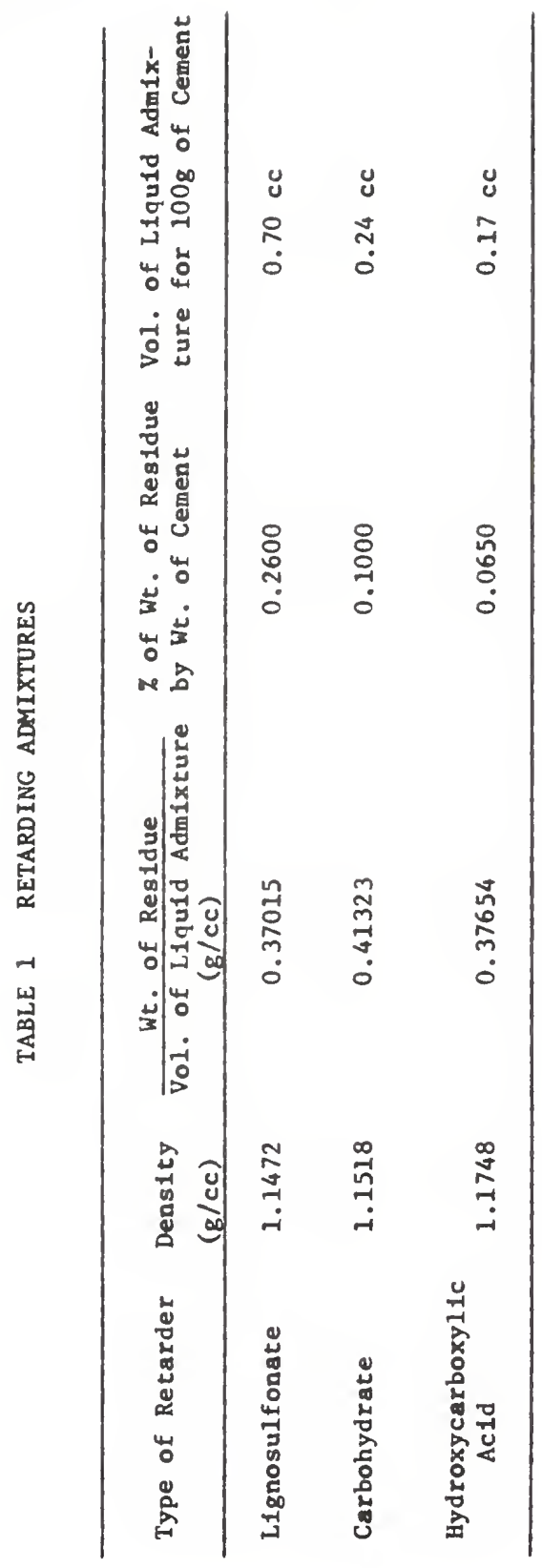


TABLE 2 CHEMICAL PROPERTIES OF CEMENT, LAB. NO. 319-1. (ASTM C 150)

\begin{tabular}{lc}
\multicolumn{1}{c}{ Compound } & Chemical Analysis \\
S1licon dioxide, $\mathrm{S}_{2} \mathrm{O}_{2}$ & 21.64 \\
Aluminum oxide, $\mathrm{Al}_{2} \mathrm{O}_{3}$ & 5.29 \\
Ferric oxide, $\mathrm{Fe}_{2} \mathrm{O}_{3}$ & 2.19 \\
Calcium oxide, $\mathrm{CaO}$ & 65.36 \\
Magnesium oxide, $\mathrm{Mg}_{3}$ & 0.92 \\
Sulfur trioxide, $\mathrm{SO}_{3}$ & 2.40 \\
Loss on 1gnition & 1.89 \\
Total alkalies, as $\mathrm{Na}_{2} \mathrm{O}$ & 0.35 \\
Free lime & 1.08 \\
Insoluble residue & 0.25
\end{tabular}

Potential Compound Composition

$\begin{array}{cc}\text { Compound } & \text { Percentage present } \\ \text { Tricalcium silicate, } \mathrm{C}_{3} \mathrm{~S} & 56.03 \\ \text { Dicalcium silicate, } \mathrm{C}_{2} \mathrm{~S} & 19.86 \\ \text { Tricalcium aluminate, } \mathrm{C}_{3} \mathrm{~A} & 10.31 \\ \text { Tricalcium alumino ferrite, } \mathrm{C}_{4} \mathrm{AF} & 6.66 \\ \text { Calcium sulfate, CaSO } & 4.08\end{array}$


TABLE 3 PHYSICAL PROPERTIES OF CEMENT, LAB. NO. 319-1. (ASTM C 150)

SETTING TIMES
Inttial
$2 \mathrm{hr} .55 \mathrm{~min}$.
Final
$4 \mathrm{hr} .15 \mathrm{~min}$.
V1cat
$1 \mathrm{hr} .55$ min.

FINENESS

$\begin{array}{ll}\text { No. } 325 \text { sleve } & 93.7 \text { percent } \\ \text { Wagner } & 1990 \mathrm{~cm}^{2} / \mathrm{g} \\ \text { Blaine } & 3870 \mathrm{~cm}^{2} / \mathrm{g}\end{array}$

AIR CONTENT OF MORTAR

8.3 percent

EXPANSION

0.136 percent

TENSILE STRENGTH

$\begin{array}{ll}\text { One day } & 205 \text { ps1 } \\ \text { Three days } & 345 \text { ps1 } \\ \text { Seven days } & 430 \mathrm{p} 81 \\ \text { Twenty-eight days } & 520 \mathrm{ps} 1\end{array}$

COMPRESSIVE STRENGTH

$\begin{array}{ll}\text { One day } & 1550 \text { ps1 } \\ \text { Three days } & 3130 \text { ps1 } \\ \text { Seven days } & 4600 \text { ps1 } \\ \text { Twenty-e1ght days } & 6450 \text { ps1 }\end{array}$


only, was sleved through No. 50 sleve and stored in sealed glass bottles before using.

Water

For preparation of cement paste, delonlzed water was used for mix water.

\section{Apparatus and Equipment}

An apparatus designed to measure plastic shrinkage of cement paste has been described by Cromarty and Bryden (16). In designing their apparatus they considered the effect of restraint between the specimen and 1 ts support, and the effect of size of the specimen. They used a mercury bed to reduce the effect of restraint, and a gage length of 5 In $(12.7 \mathrm{~cm})$ to secure the desired accuracy of the measurement of length changes. The same concept was used by Orr, Mice and Halgh (15), who used a gage length of $15 \mathrm{~cm}$, to permit measurement of the larger strains which are assoclated with conditions under which the plastic shrinkage cracking is likely to occur. In the present work also, a gage length of $15 \mathrm{~cm}$ was used.

The general arrangement of the apparatus and other necessary equipment required is shown in Flgure 1. The apparatus, bullt of plexiglass, rests on an aluminum plate $62 \mathrm{~cm} 10 \mathrm{ng}, 27 \mathrm{~cm}$ wide and $2.5 \mathrm{~cm}$ thick. Three foot screws are provided to level the mercury in the tank. The main apparatus with the base plate is shown in Flgure 2. Speclmens with a gage length of $15 \mathrm{~cm}$ and a cross-section of $2.5 \mathrm{~cm}$ by $0.65 \mathrm{~cm}$ were chosen. A small box in the main apparatus, 


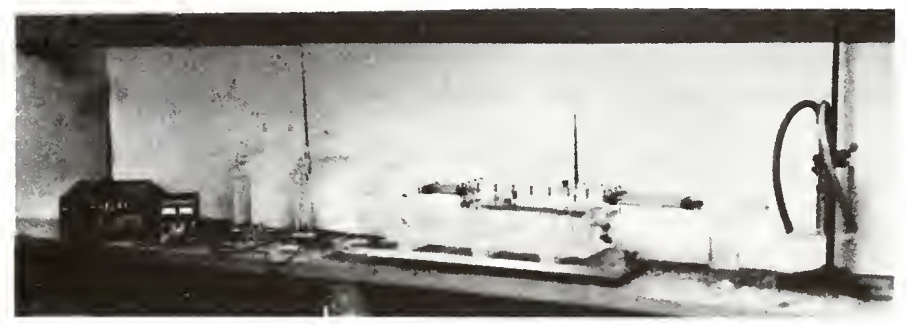

FIGURE 1 EXPERIMENTAL SET UP FOR SHRINKAGE MEASUREMENT

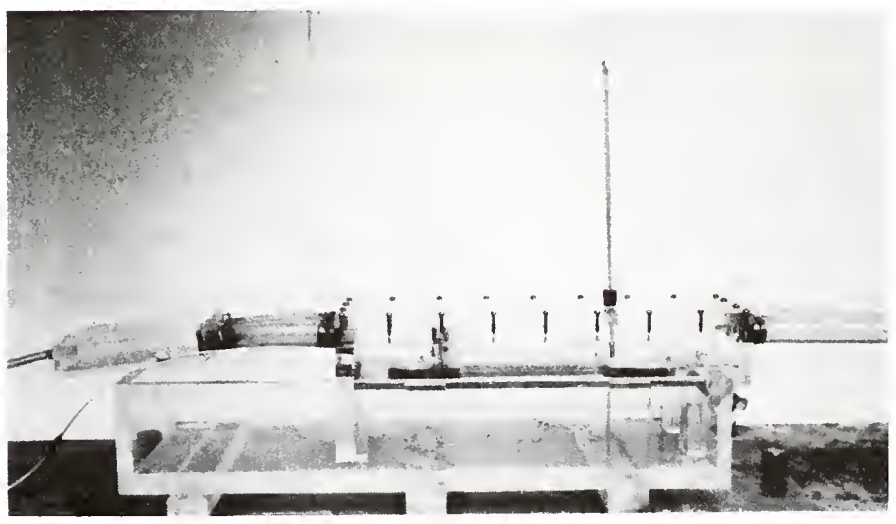

FIGURE 2 SAMPLE CHAMBER 
measuring $38.5 \mathrm{~cm}$ long, $11 \mathrm{~cm}$ wide and $6.5 \mathrm{~cm} \mathrm{high,} \mathrm{was} \mathrm{chosen} \mathrm{to}$ contaln the specimen while measuring plastic shrinkage. The shape of the specimen 18 shown in Figure 3. The top plate for the box Is provided with screws so that after casting the specimen, the box can be made alr tight. The mold for the specimen on the mercury bed $(0.65 \mathrm{~cm}$ thick) $18 \mathrm{~s}$ shown in Figure 3. One end of the specimen 18 attached to the fixed head; the other end to the movable head. The stralght portion of the specimen in between the movable and fixed heads is taken as the gage length. The fixed head 1s attached to the sides of the box leaving $0.65 \mathrm{~cm}$ from the bottom. The movable head and the specimen were allowed to float on the mercury bed, which was provided to reduce the restraining effect of the bottom surface of the specimen when it shrinks.

To measure the changes in length of the speclmen, the previous 1nvestigators (15, 16) used an LVDT (Linear Varlable Differential Transformer). In this present work a magnetic proximeter, Bently Nevoda, model No. 3115 and a probe model No. $308 \mathrm{~L} 18$ were used for simplicity and the elimination of frictional resistance. The magnetic proximeter, the probe, the voltage regulator and the digital voltmeter with micrometer are shown in Figure 4. In this figure the probe is flxed in position in front of the mfcrometer. After placing the steel target, with a thickness of 0.004 Inch, in position in front of micrometer, the set up shown in Figure 4 was used to get the calibration curve. Th1s 18 a curve of output voltage versus the gap between probe and steel target. While measuring the length changes of a 


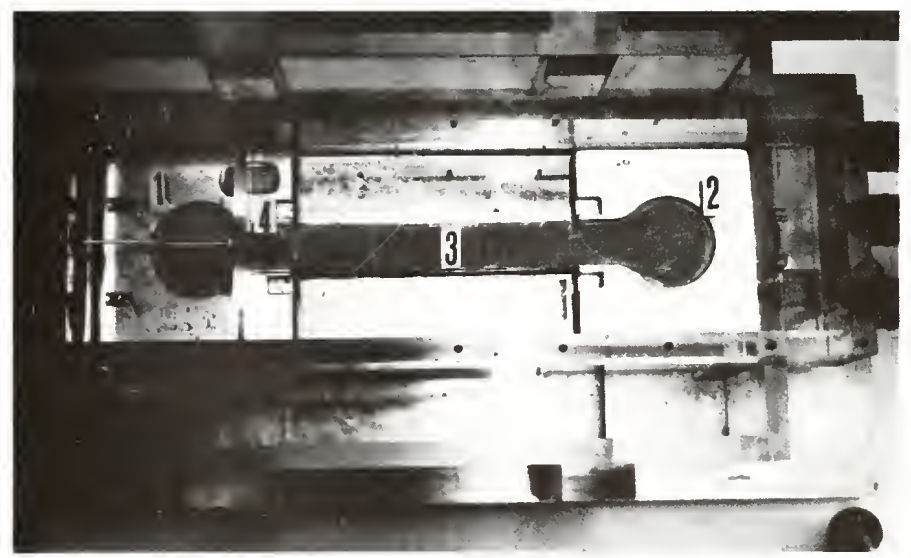

FIGURE 3 TOP VIEW OF SAMPLE CHAMBER

$\begin{array}{ll}1 \text { Movable head } & 2 \text { Fixed head } \\ 3 \text { Specimen } & 4 \text { Probe }\end{array}$

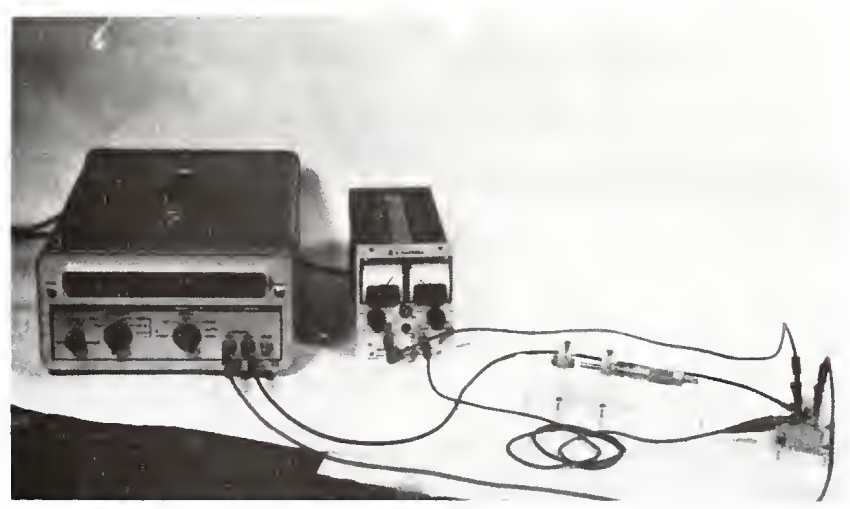

FIGURE 4 CALIBRATION SET UP 
specimen, the ateel target was positioned at the gage point (near the movable head), and the probe was fixed in front of steel target. The voltage regulator was used to regulate an input voltage of minus 18 volts which was required for the proximeter. After completing connections, the voltage in the digital voltmeter is the function of distance between the steel target and the probe.

The callbration curve (Figure 5) was prepared by ualng a micrometer heving a least count of $0.0001 \mathrm{in}$. The steel target was positioned on the front of the micrometer, which was fixed to the vertical plexiglass stand prepared for this purpose. The probe was flxed in another vertical stand in front of the steel target, and the other end of the probe was connected to the proximeter. Before connecting the probe a minus 18 volt input voltage to the proximeter was obtained with the help of the voltage regulator. Starting from zero reading in the voltmeter, the steel target almost touching the probe front face, the micrometer was adjusted to read zero. The micrometer was then repeatedly turned back, that 18 the gap between the probe and the steel target was increased repeatedly by increments of $0.0005 \mathrm{in}$, and the corresponding output voltage readings were taken. The voltmeter readings in volts versus the messured gap between the steel target and probe were then plotted.

To maintain the relative humidity constant, air was passed through vapor trap bottles containing sulfuric acld of the correct dilution to produce the desired relative humidity, and then over the specimen. The sulfurtc acid solution was adfusted for the desired relative humidty by measuring and acid adfusting its density according 
TABLE 4 CALIBRATION OF SYSTRON DONNER VOLTMETER

\begin{tabular}{|c|c|c|c|}
\hline $\begin{array}{c}\text { Micrometer } \\
\text { Reading } \\
\text { (1nch) }\end{array}$ & $\begin{array}{l}\text { Voltmeter } \\
\text { Reading } \\
\text { (volts) }\end{array}$ & $\begin{array}{l}\text { Mlcrometer } \\
\text { Reading } \\
\text { (1nch) }\end{array}$ & $\begin{array}{c}\text { Voltmeter } \\
\text { Read1ng } \\
\text { (volts) }\end{array}$ \\
\hline 0.000 & 0.000 & 0.100 & 5.620 \\
\hline 0.005 & 0.116 & 0.105 & 5.977 \\
\hline 0.010 & 0.326 & 0.110 & 6.340 \\
\hline 0.015 & 0.535 & 0.115 & 6.702 \\
\hline 0.020 & 0.737 & 0.120 & 7.034 \\
\hline 0.025 & 0.943 & 0.125 & 7.317 \\
\hline 0.030 & 1.202 & 0.130 & 7.642 \\
\hline 0.035 & 1.476 & 0.135 & 7.965 \\
\hline 0.040 & 1.755 & 0.140 & 8.292 \\
\hline 0.045 & 2.023 & 0.145 & 8.586 \\
\hline 0.050 & 2.280 & 0.150 & 8.822 \\
\hline 0.055 & 2.600 & 0.155 & 9.100 \\
\hline 0.060 & 2.937 & 0.160 & 9.379 \\
\hline 0.065 & 3.272 & 0.165 & 9.648 \\
\hline 0.070 & 3.587 & 0.170 & 9.887 \\
\hline 0.075 & 3.884 & 0.175 & 10.08 \\
\hline 0.080 & 4.438 & 0.180 & 10.30 \\
\hline 0.085 & 4.607 & 0.185 & 10.52 \\
\hline 0.090 & 4.976 & 0.190 & 10.72 \\
\hline 0.095 & 5.316 & 0.195 & 10.91 \\
\hline
\end{tabular}




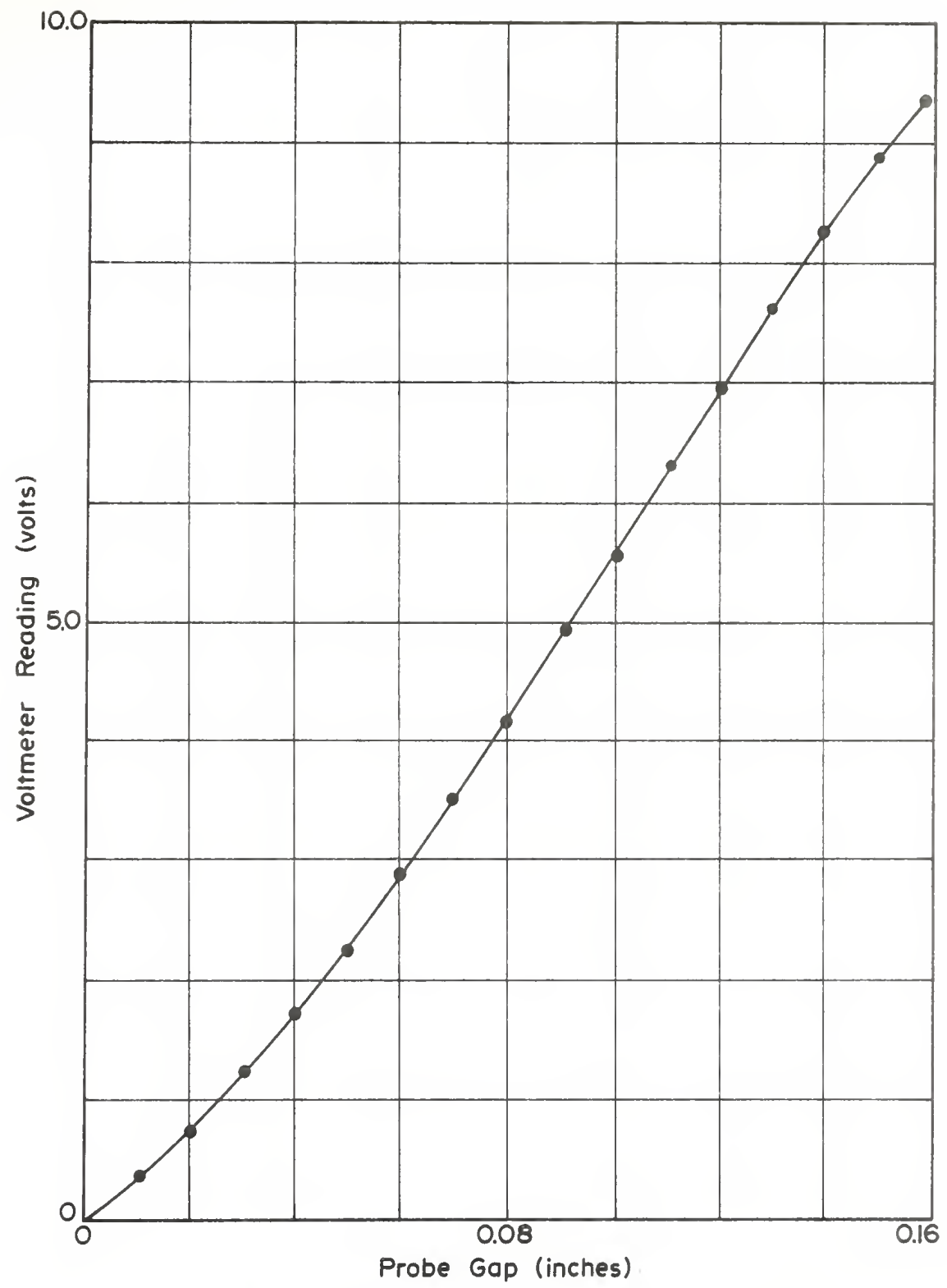

FIGURE 5 - CALIBRATION OF SYSTRON DONNER VOLTMETER. 
to ASTM E 104-51. F1gura 6 111ustrates the vapor trap bottles. Constant flow was malntained with the aid of a water manometer by keeping one $\mathrm{cm}$ constant head. An asplrator was used to draw the air through sulfuric acid solution. The relative humidities obtained were verifled by using a relative humidity sensor, placed inside the sample conteiner. A thermometer was inserted from the top of the box to record the temperature during the experiment.

\section{Procedure}

Mixing the Cement Paste

$115 \mathrm{~g}$ of cement was weighed using a triple beam balance, and transferred to a friction top can. A new can was used for each mix. When using a retarding admixture, stock solution of the admixture sufficient for five experiments and fifty percent retardation was prepared. The prepared solution was used within a week after preparation. The solution required for a water cement ratio of 0.35 by welght was then measured by graduated cylinder and added to the cement. Using mechanical paint mixer, the cement and water were mixed for two minutes. As soon as the mixing perlod was over the can was opened and again mixed with a steel spoon to make sure the paste was mixed completely.

Preparation of the Specimen

The specimen was cast on a mercury bed by placing two straight plexiglass form pieces with thickness of $0.65 \mathrm{~cm}$, between the movable 
and fixed heads. While casting the specimen an 0.004 in. thick steel target was positioned at the gage point near the movable head. The specimen was levelled to the surface of the side plexiglass form pleces. The probe was fixed in front of the steel target and connected to the proximeter. Figure 7 11lustrates the arrangement of the probe. After casting, the side plexiglass pleces were removed carefully without disturbing the specimen. The top plate was screwed tight to the box and the joints around 1 sealed with electric tape to make the chamber alr tight.

Alr drawn through the sulfuric acld solution was allowed to pass over the specimen, and the amount of flow was controlled by keeping a one $\mathrm{cm}$ head of water in the water manometer. With the help of the voltage regulator, a minus 18 volts reading wss secured as the input voltages to the proximeter. The first reading was taken after connecting the probe to the proximeter. The time elapsed between the water added and the first reading taken was maintained as 20 minutes for all experiments. For the purpose of calculation, the time of first resding taken was considered to be zero. Up to the equilibrium shrinkage stage voltmeter readings were recorded. For the calculation of shrinkage the distance between the movable and fixed heads was considered as the gage length and was $15 \mathrm{~cm}(5.9$ inches).

\section{Measurement of Plastic Shrinkage}

Following the procedures prevlously presented, voltmeter readings for each experiment were recorded perfodically to determine the change 


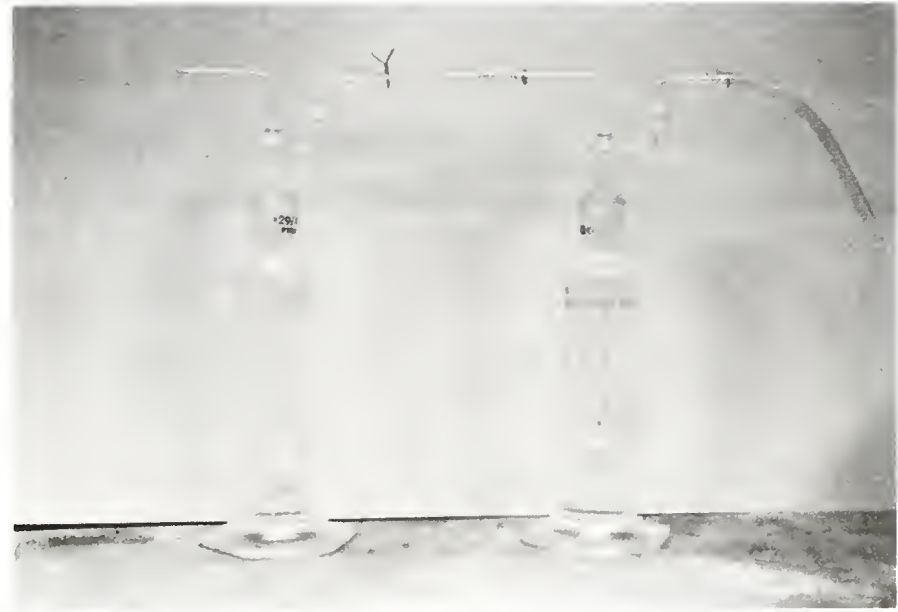

FIGURE 6 VAPOR TRAP BOTTLES WITH SULFURIC ACID SOLUTION

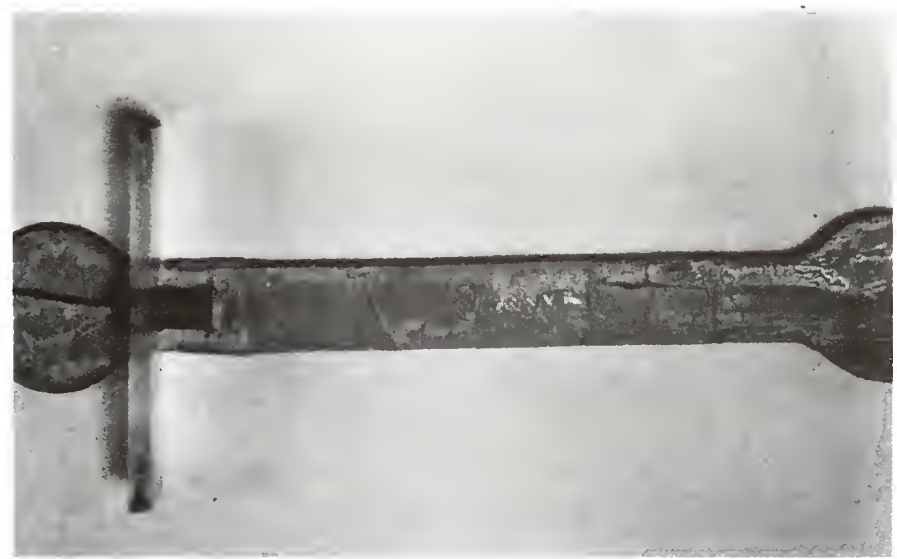

FIGURE 7 ARRANGEMENT OF PROBE AND STEEL TARGET WHEN MEASURING LENGTH CHANGE 
In gap between the probe and the steel target resulting from shrinkage. From the callbration curve for the change of voltage, the correspondIng change in probe gap which is equivalent to the linear deformation was calculated. By using a gage length of $15 \mathrm{~cm}$ (5.9 inches) the shrinkage strains in millionths ware calculated and tabulated. 


\section{RESULTS}

\section{V1cat Setting Times}

Vicat setting times for pastes made with water cement ratio 0.35 by weight are tabulated in the Table 5. V1cat setting times were determined for both plain paste and paste containing retarding admixtures. The procedure for conducting the Vicat setting time experiment was followed according to the ASTM C 191-71. It should be noted that the different water cement ratlos were used in the penetration resistance test and in the VIcat setting time experiment. In the penetration resistance test, mortar of water cement ratio 0.50 by weight was used. V1cat setting times were determined on cement pastes of water cement ratio 0.35 by welght, since this water cement ratio was used in the plastic shrinkage experiments.

\section{Plastic Shrinkage}

Measurements of the plastic shrinkage of plain and retarded portland cement pastes were carrled out at three different relative humidities, 25, 50 and 75 percent. In Tables $6-17$, the measured voltage, which is a function of distance between the probe and steel target, and the calculated linear shrinkage in mfllionths, are tabulated. Voltage readings were recorded unt1l thelr change was negliglble 1.e. shrinkage ceased. A sample calculation is given in the Appendix. 
TABLE 5 VICAT SETTING TIMES FOR PASTES

\begin{tabular}{llcc}
\hline $\begin{array}{l}\text { Description } \\
\text { of Paste }\end{array}$ & $\begin{array}{c}\text { Water:Cement } \\
\text { Rat10 by Wt. }\end{array}$ & $\begin{array}{c}\text { Nol of Liquid } \\
1008 \text { of Cement }\end{array}$ & $\begin{array}{c}\text { Vicat Setting } \\
\text { Times }\end{array}$ \\
\hline $\begin{array}{l}\text { Pla1n } \\
\begin{array}{l}\text { W1th Ligno- } \\
\text { sulfonate }\end{array}\end{array}$ & 0.35 & - & $215 \mathrm{~min}$. \\
$\begin{array}{l}\text { W1th Carbo- } \\
\text { hydrate }\end{array}$ & 0.35 & $0.70 \mathrm{cc}$ & $360 \mathrm{~min}$. \\
$\begin{array}{l}\text { W1th Hydroxy- } \\
\text { carboxyl1c Ac1d }\end{array}$ & 0.35 & $0.24 \mathrm{cc}$ & $370 \mathrm{~min}$. \\
\hline
\end{tabular}

PIgures 8,9 and 10 are the plots of Iinear shrinkage in percent versus time in hours at different relative humidities. The inftial expansion recorded was followed by contraction in all cases. The inftial expansion was probably due to the formation of ettringlte in the paste. This early expansion is more predominent in plain paste as compared to the pastes with the retarders. When retarders were used, a higher rate of shrinkage soon overshadows the Initial exppansion. As the initial stiffening of cement paste 1ncreases, shrinkage Increase at a constent rate. The slope of the curve and ending of IInearlty are different for different curves.

In the Figure 9, the Inftial expansion in the case of plain paste is noticeable compared to the other three curves. The rate of shrinkage (the slope) is same for both plain pastes and those made with hydroxycarboxylic acld. A different and slightly lower rate of 


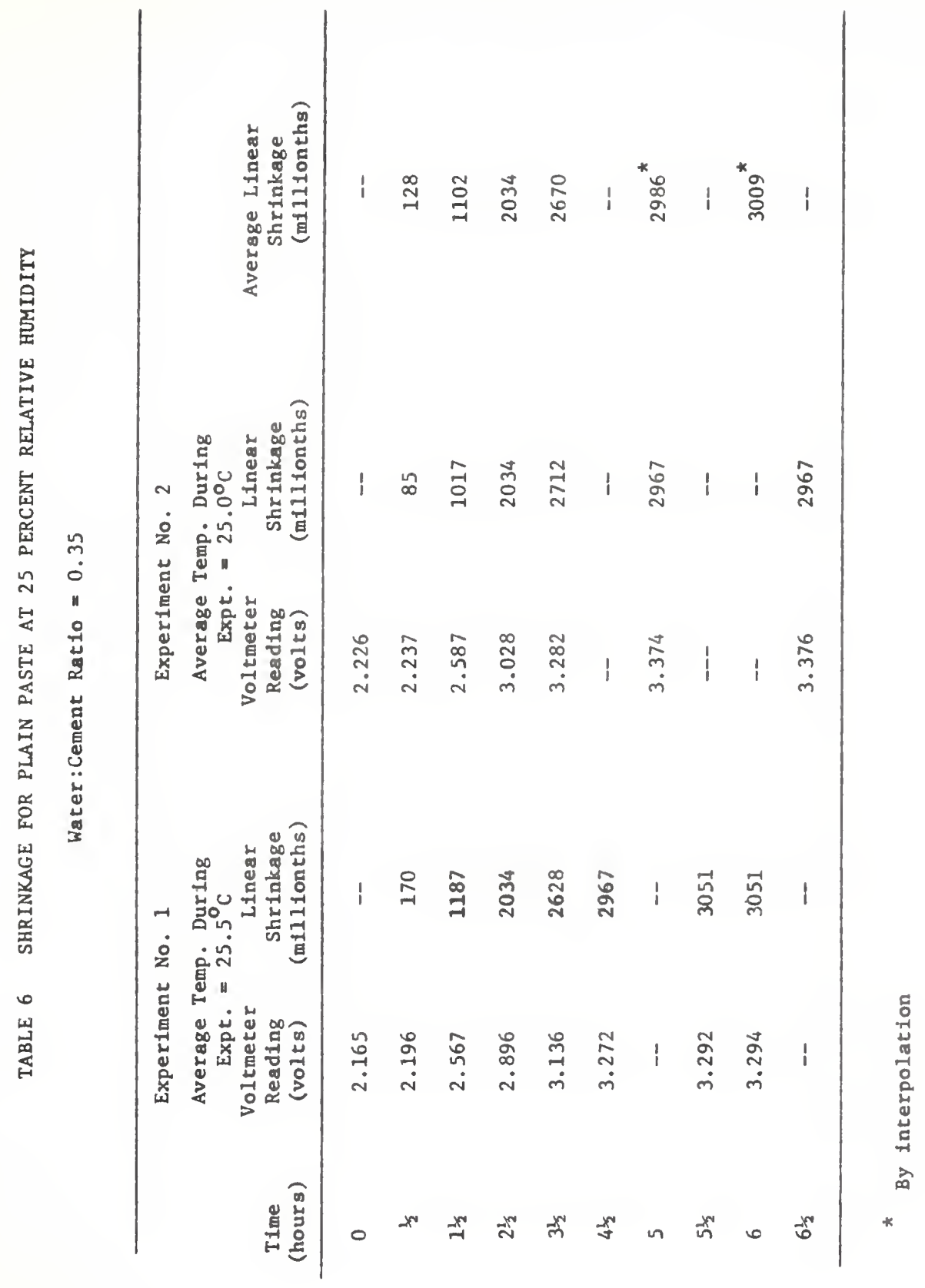




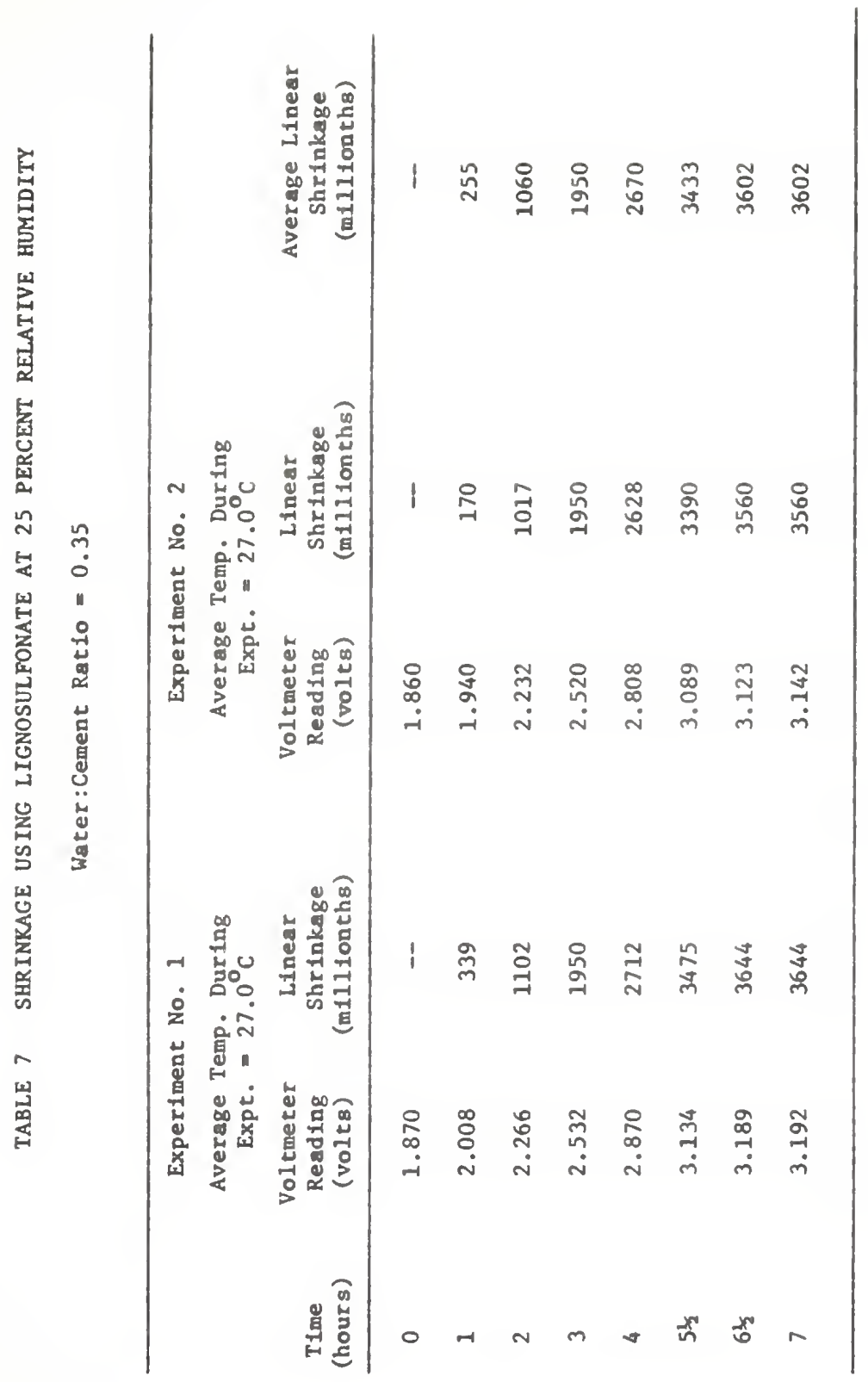




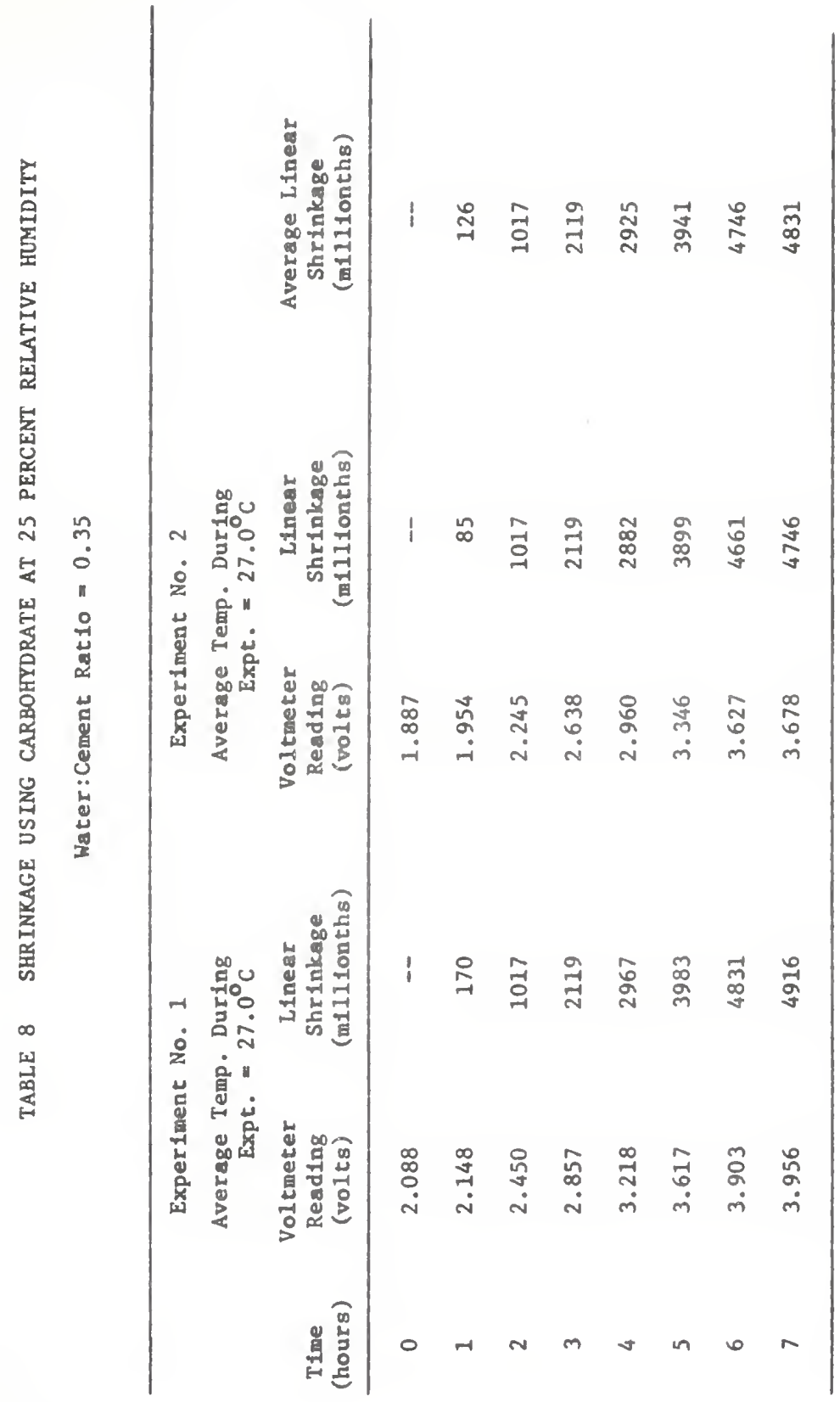




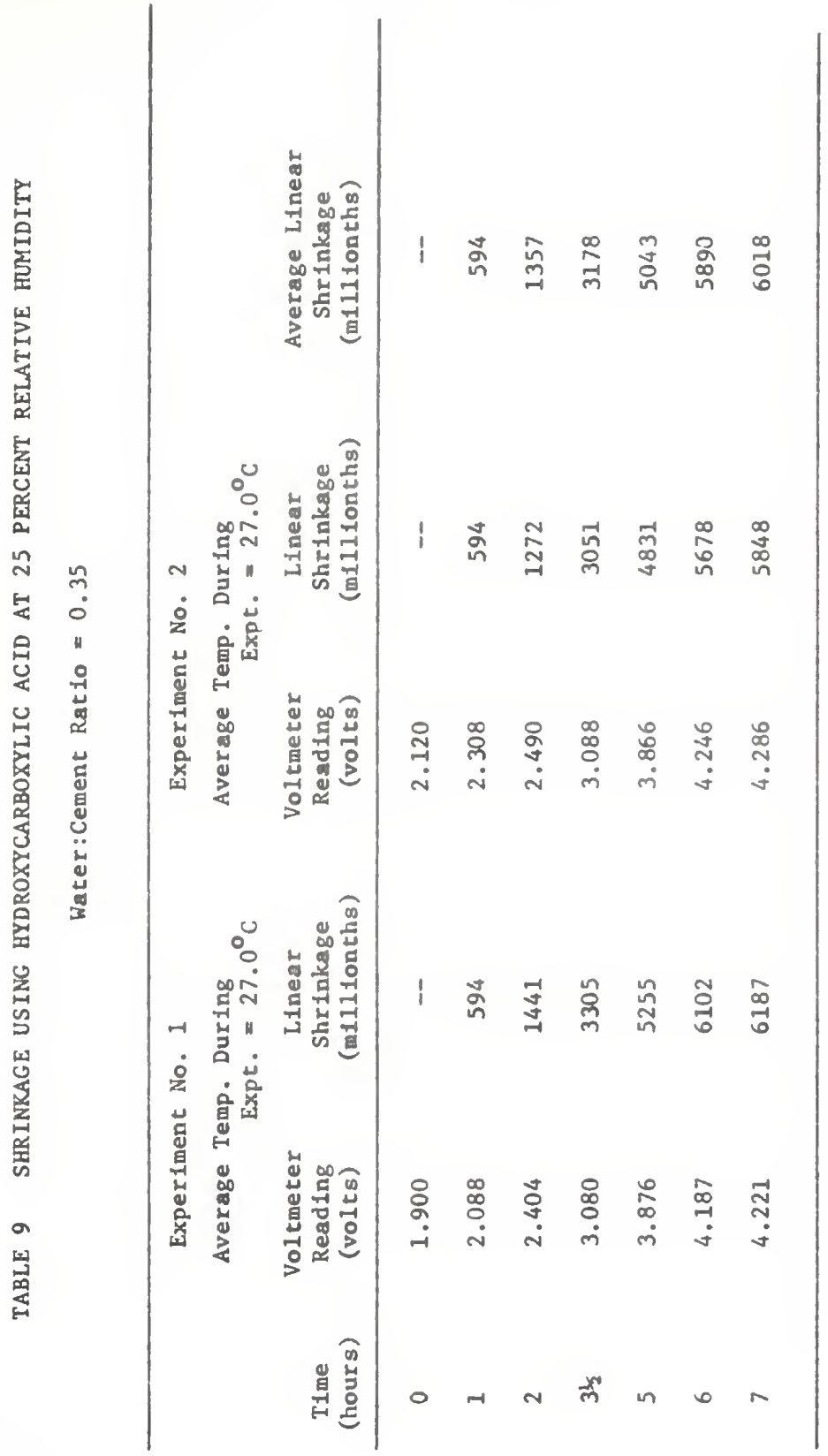




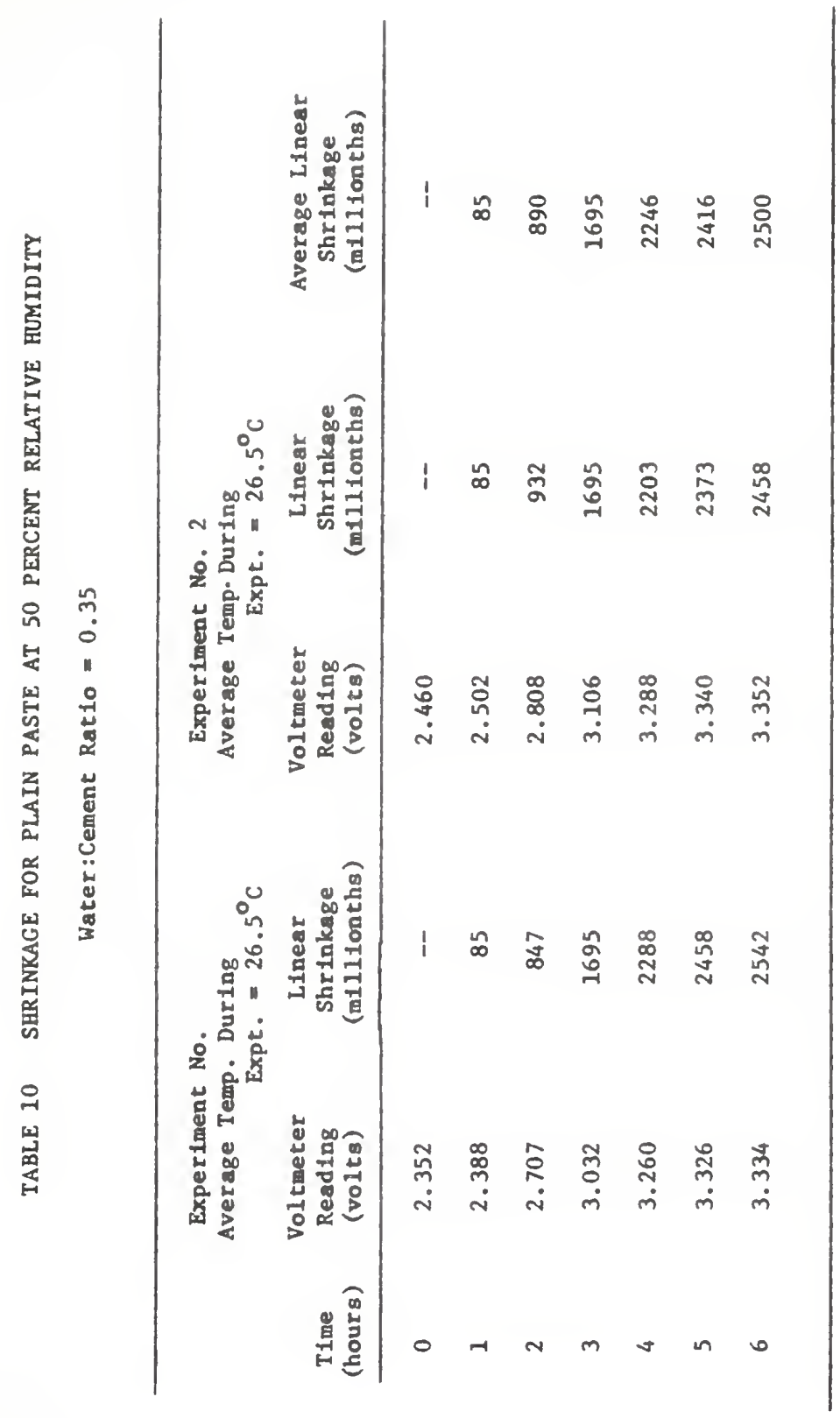




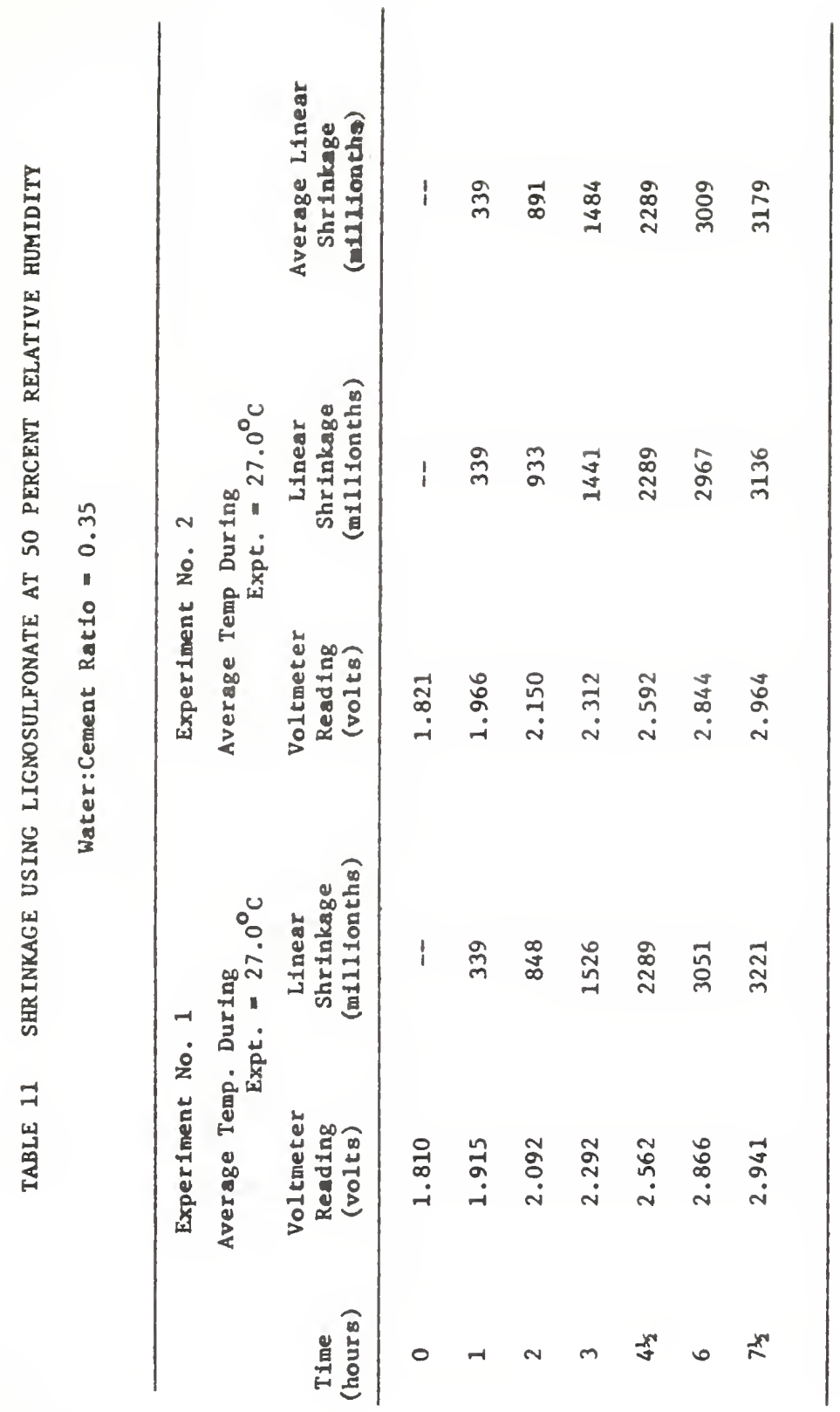




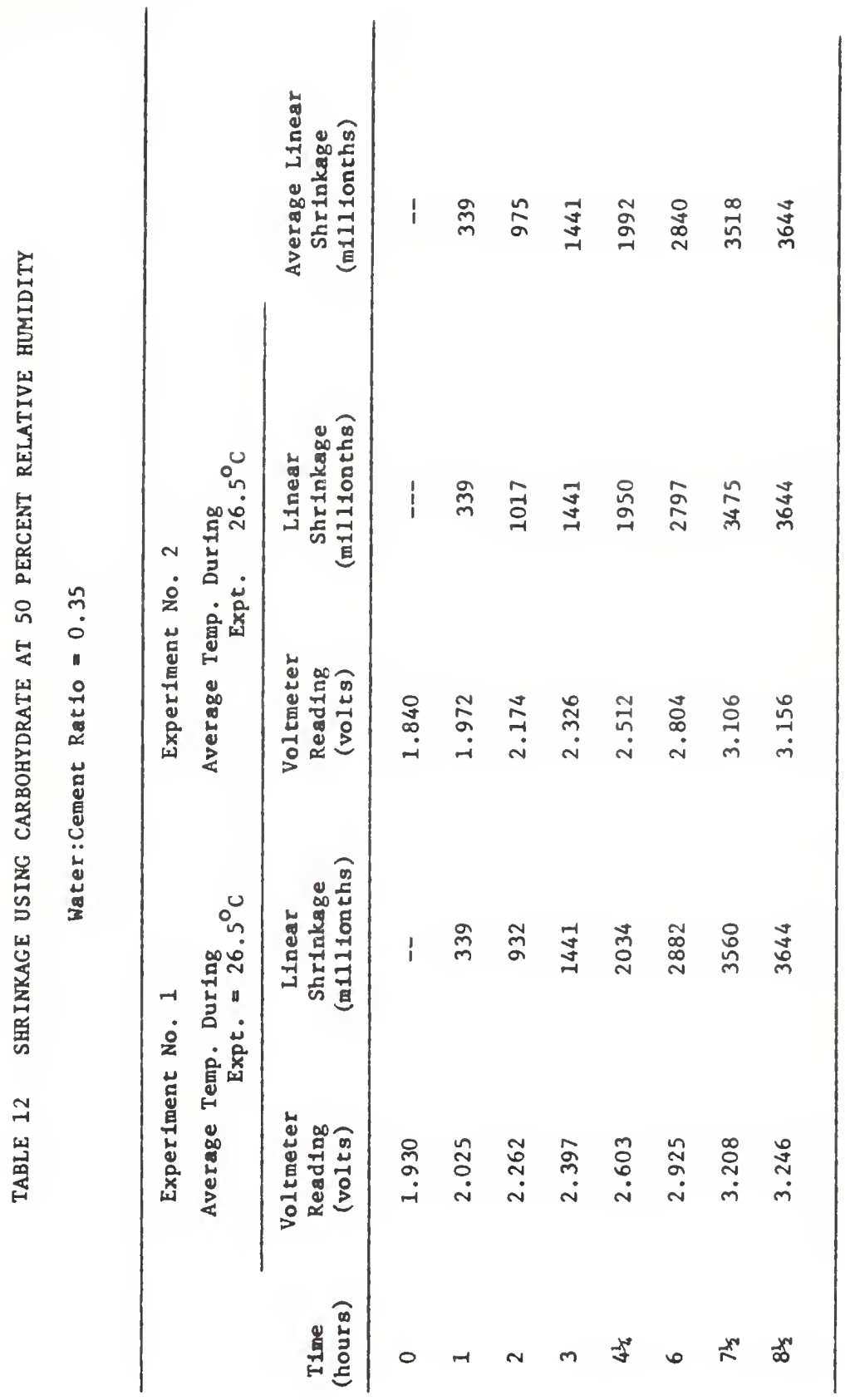


.

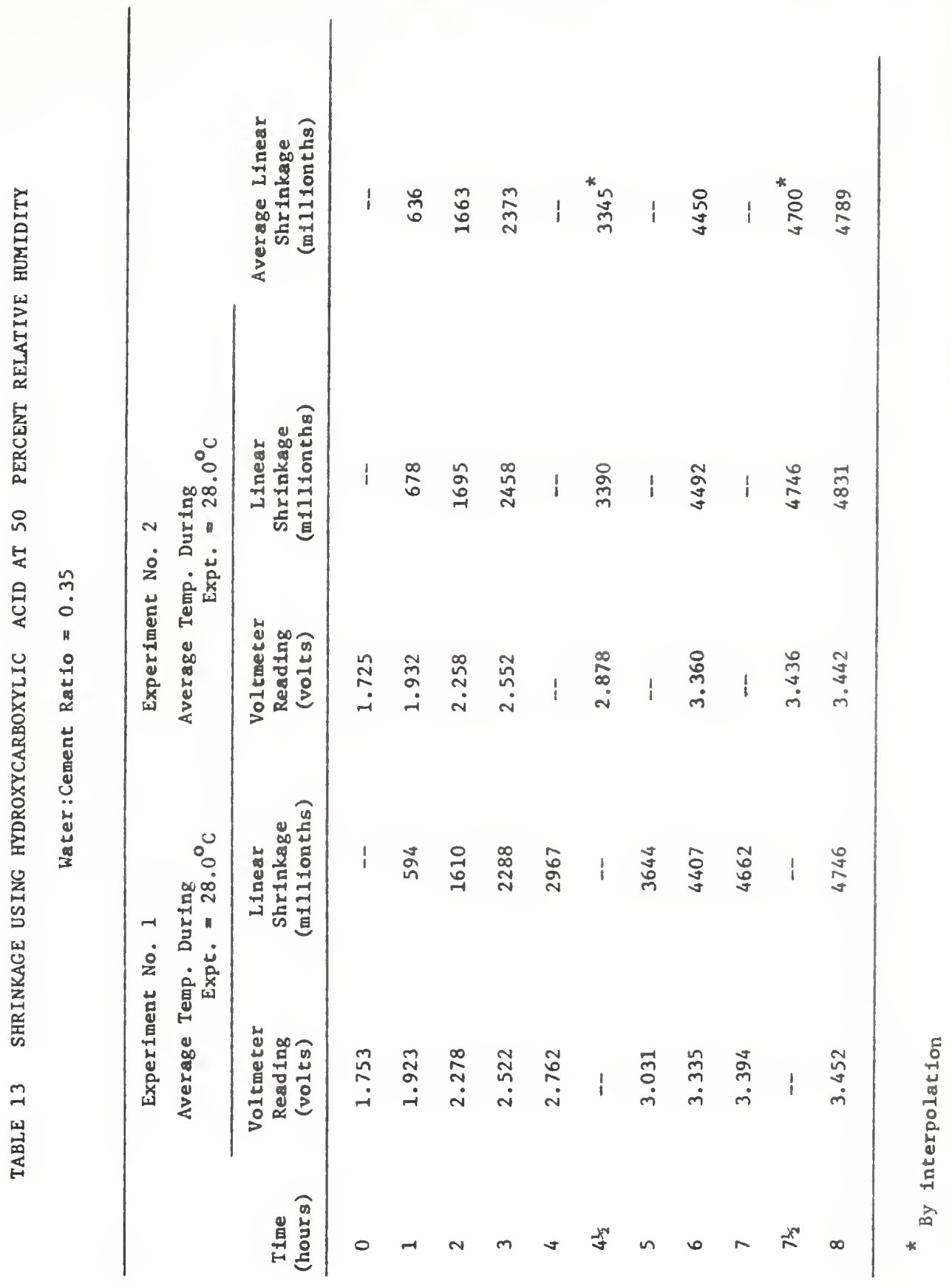




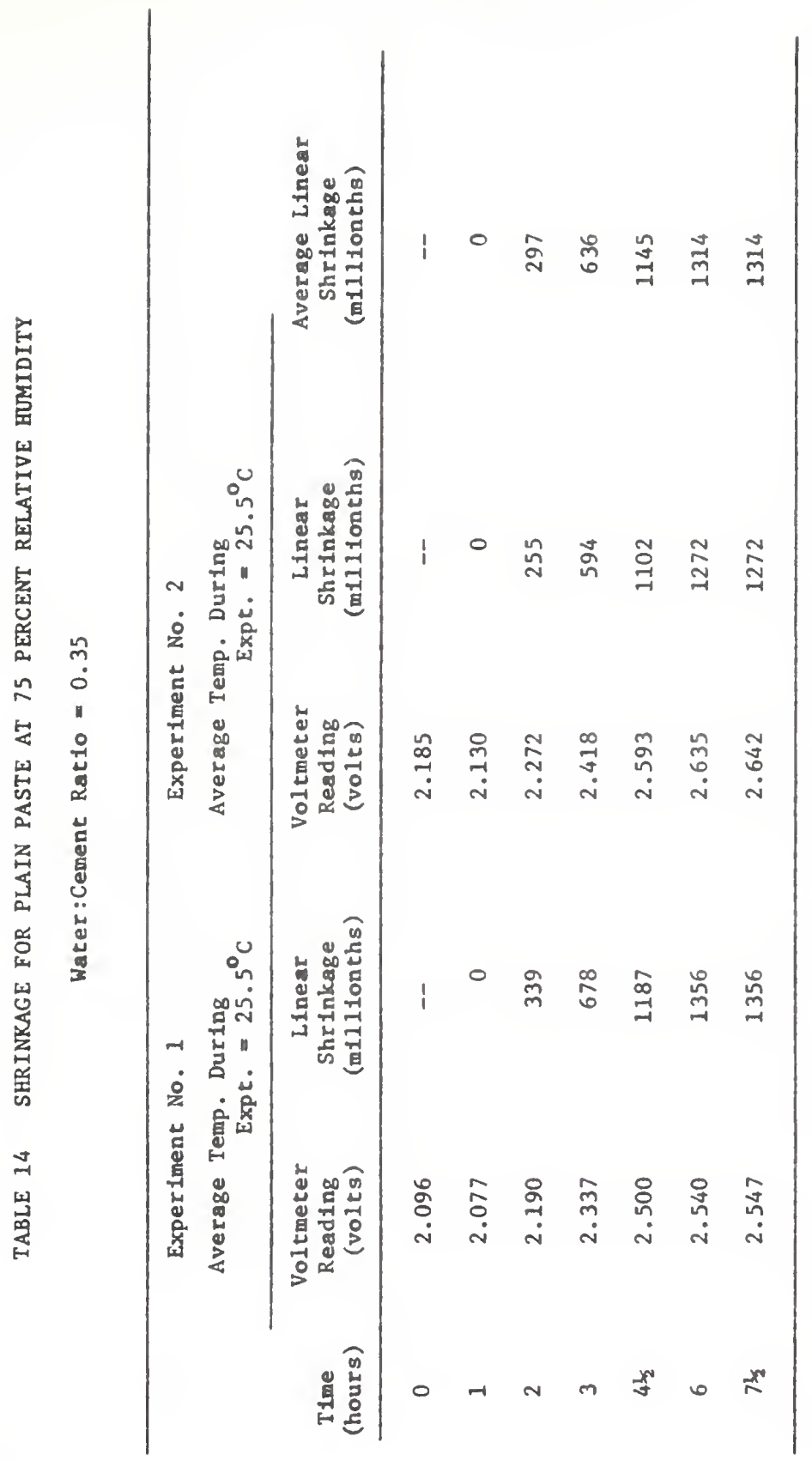




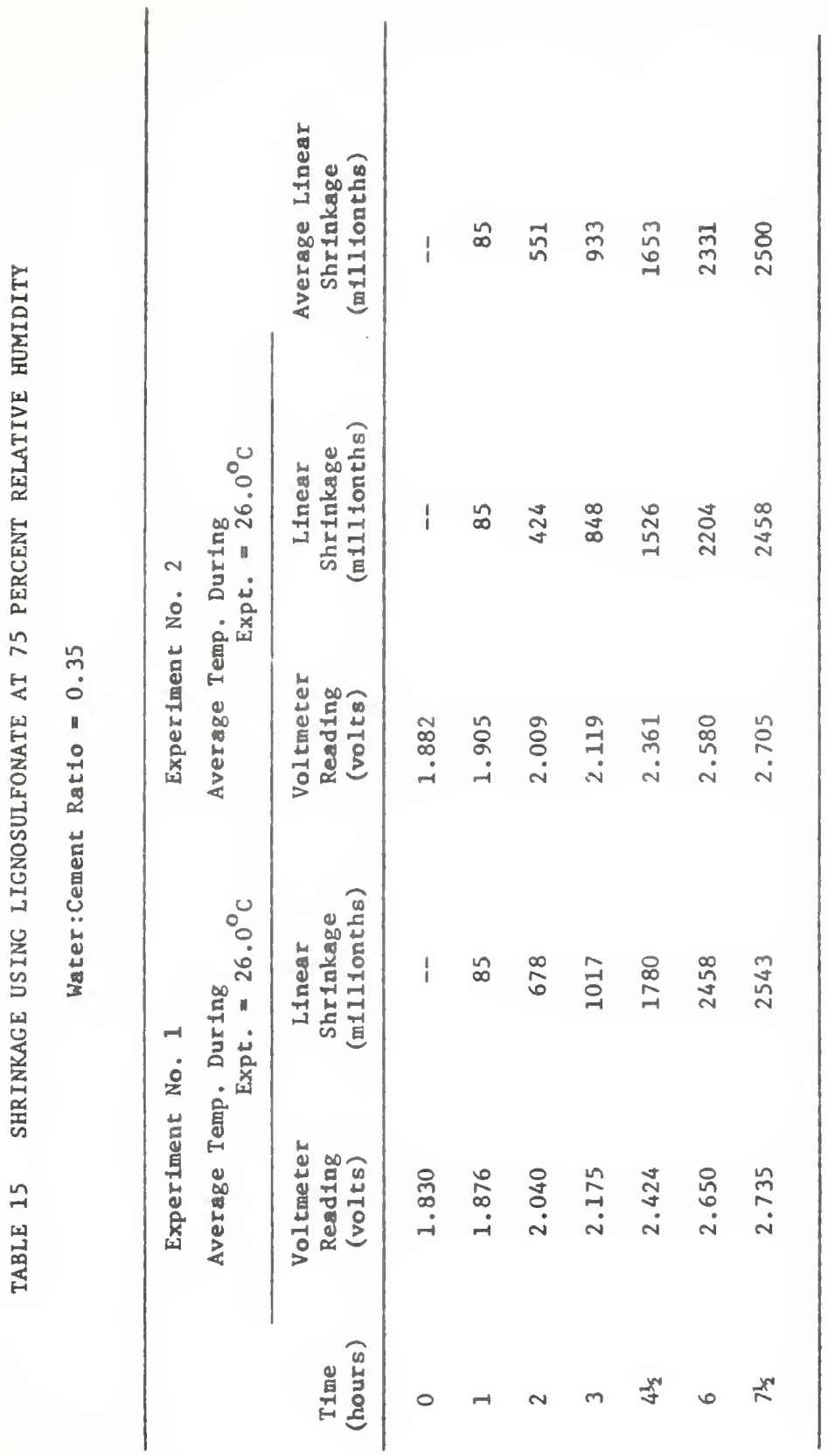




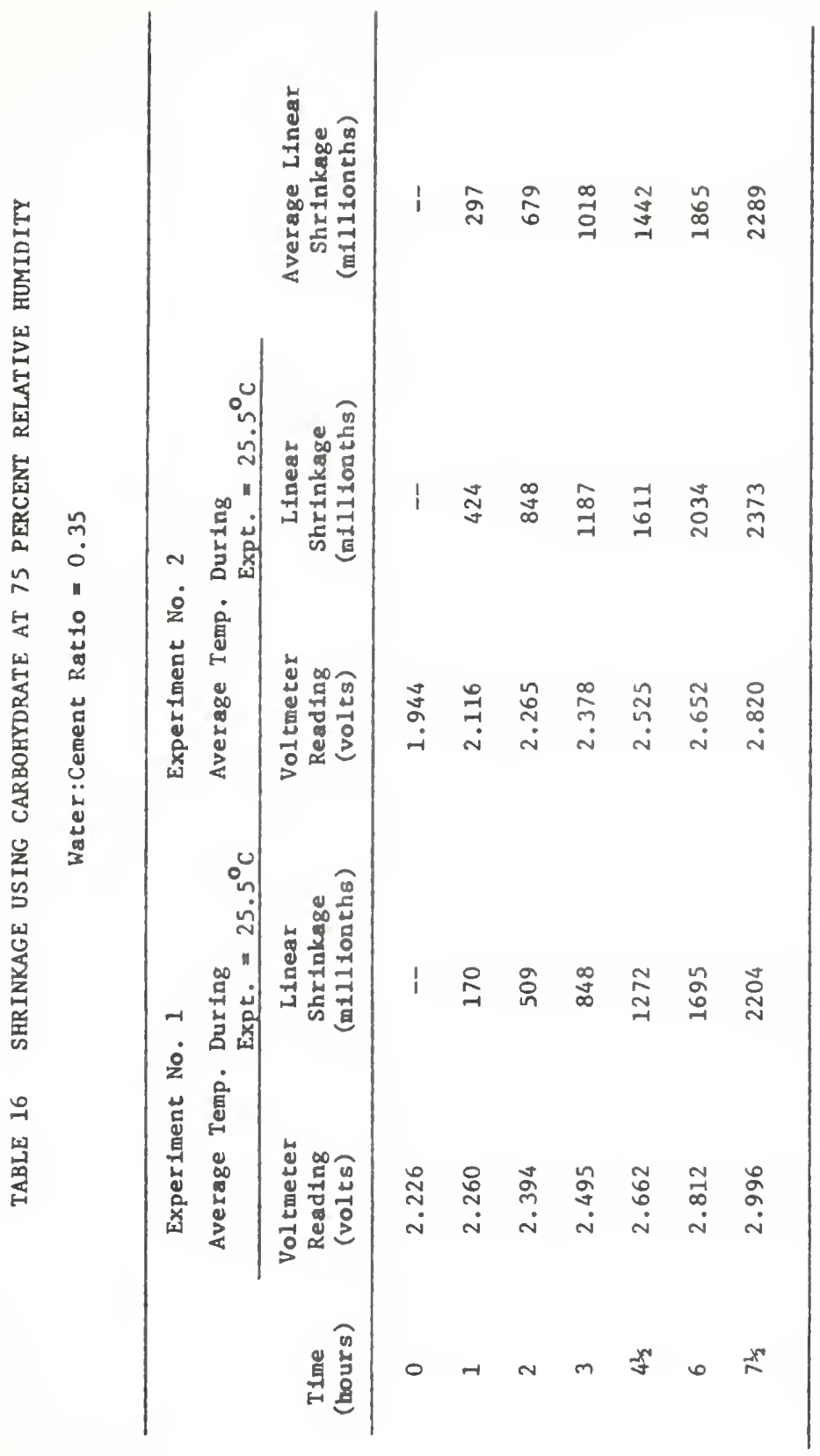




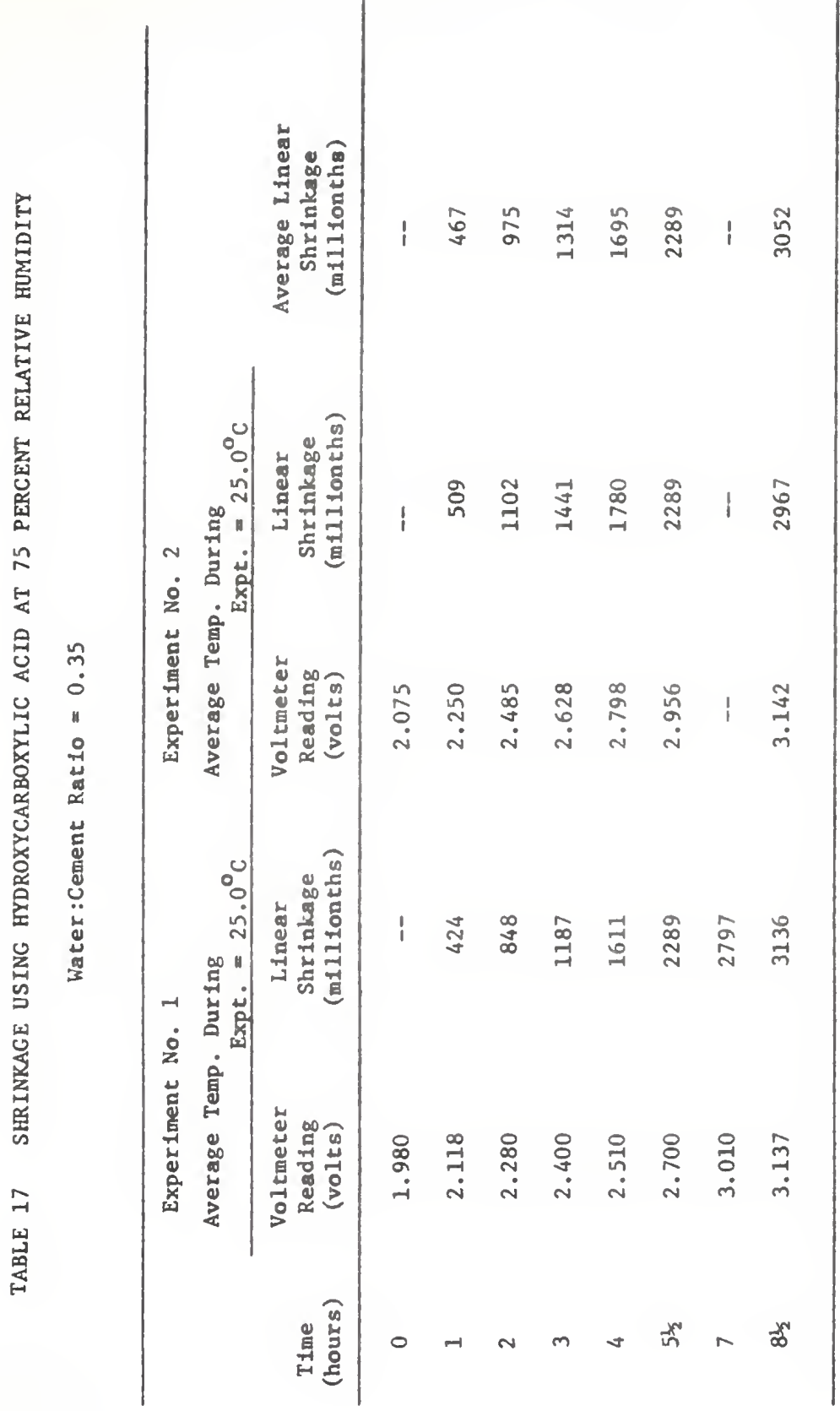




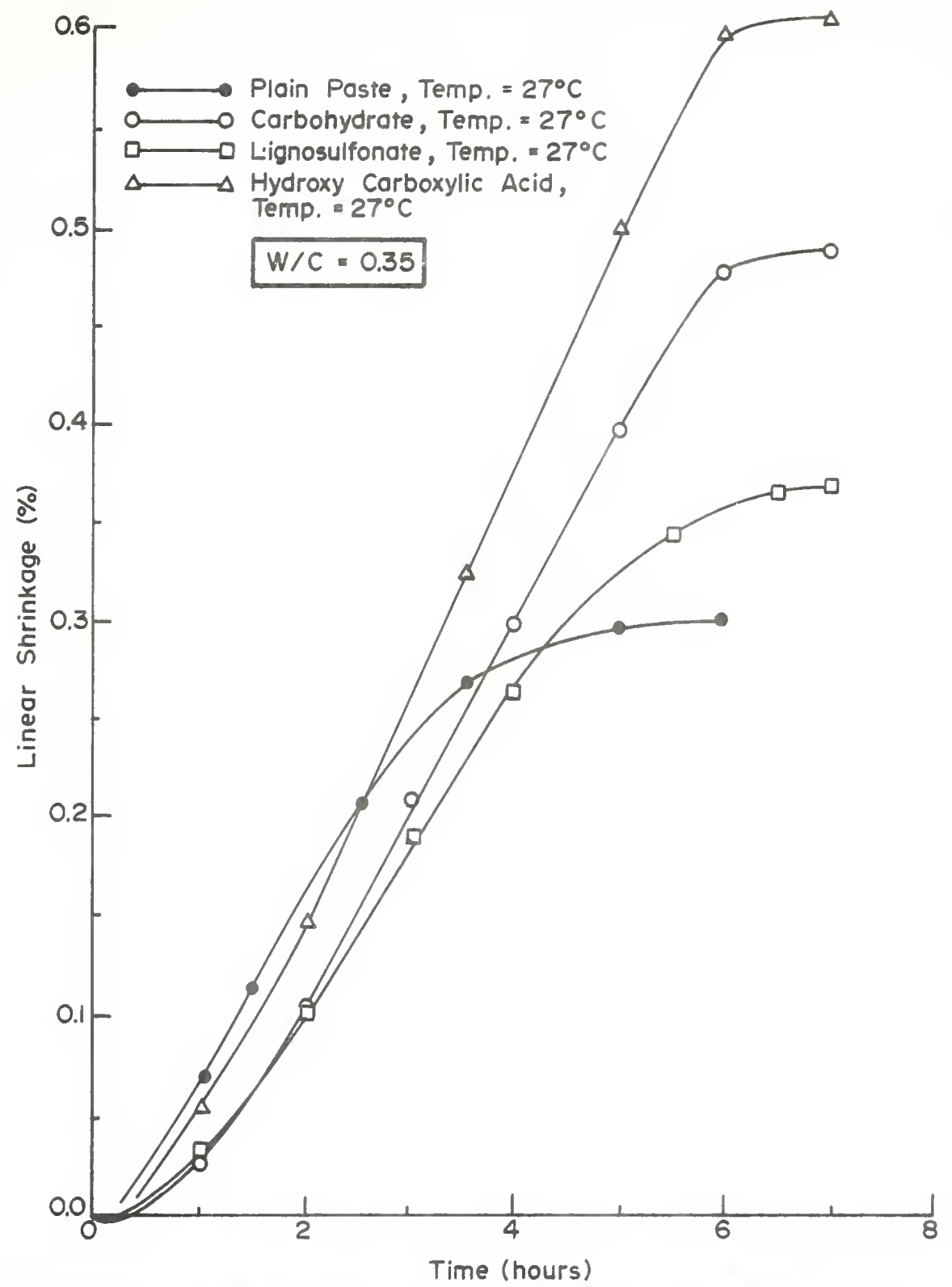

FIGURE 8 -COMPARISON OF SHRINKAGE AT $25 \%$ RELATIVE HUMIDITY. 


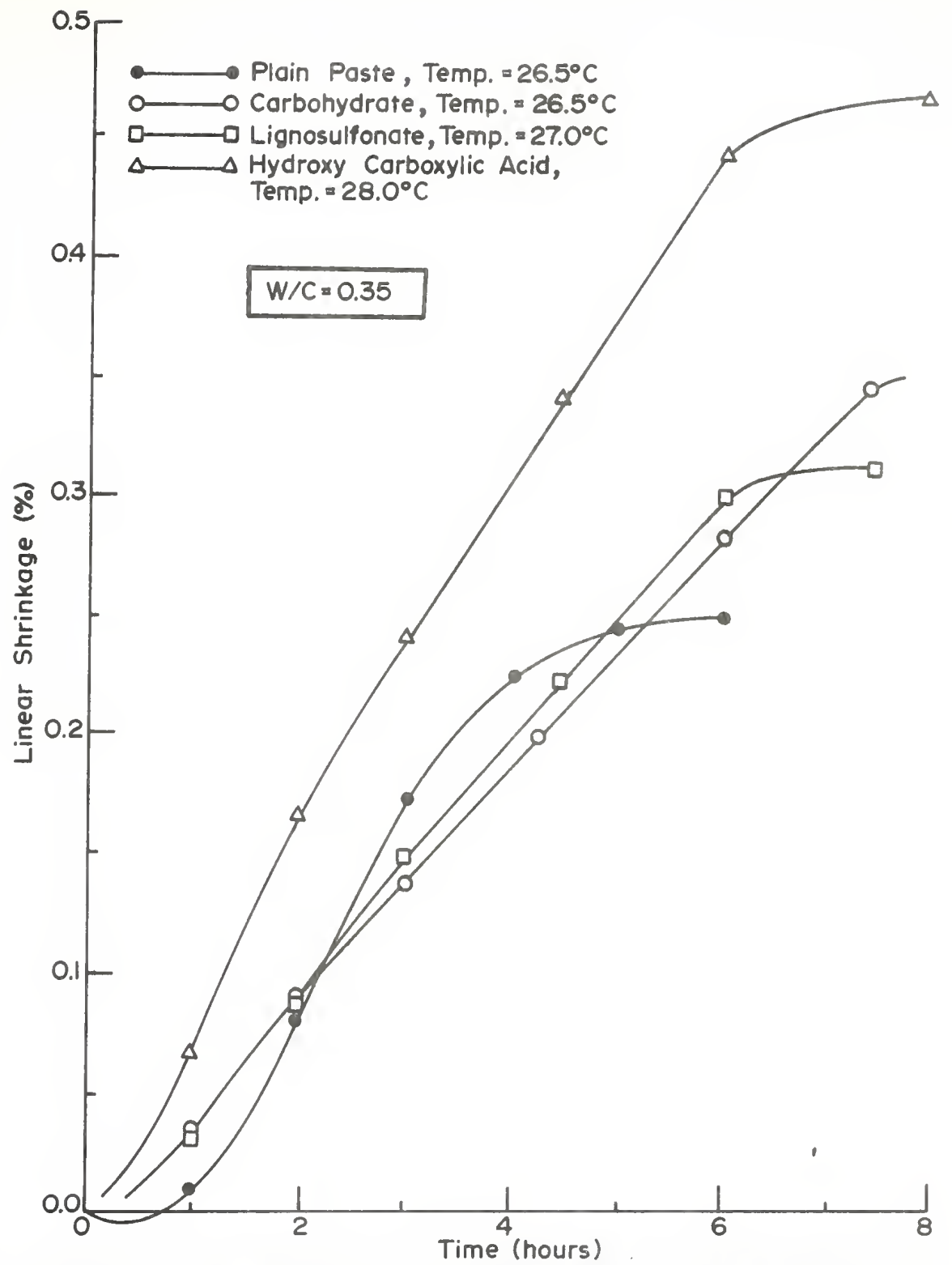

FIGURE 9 - COMPARISON OF SHRINKAGES AT 50\% RELATIVE HUMIDITY. 


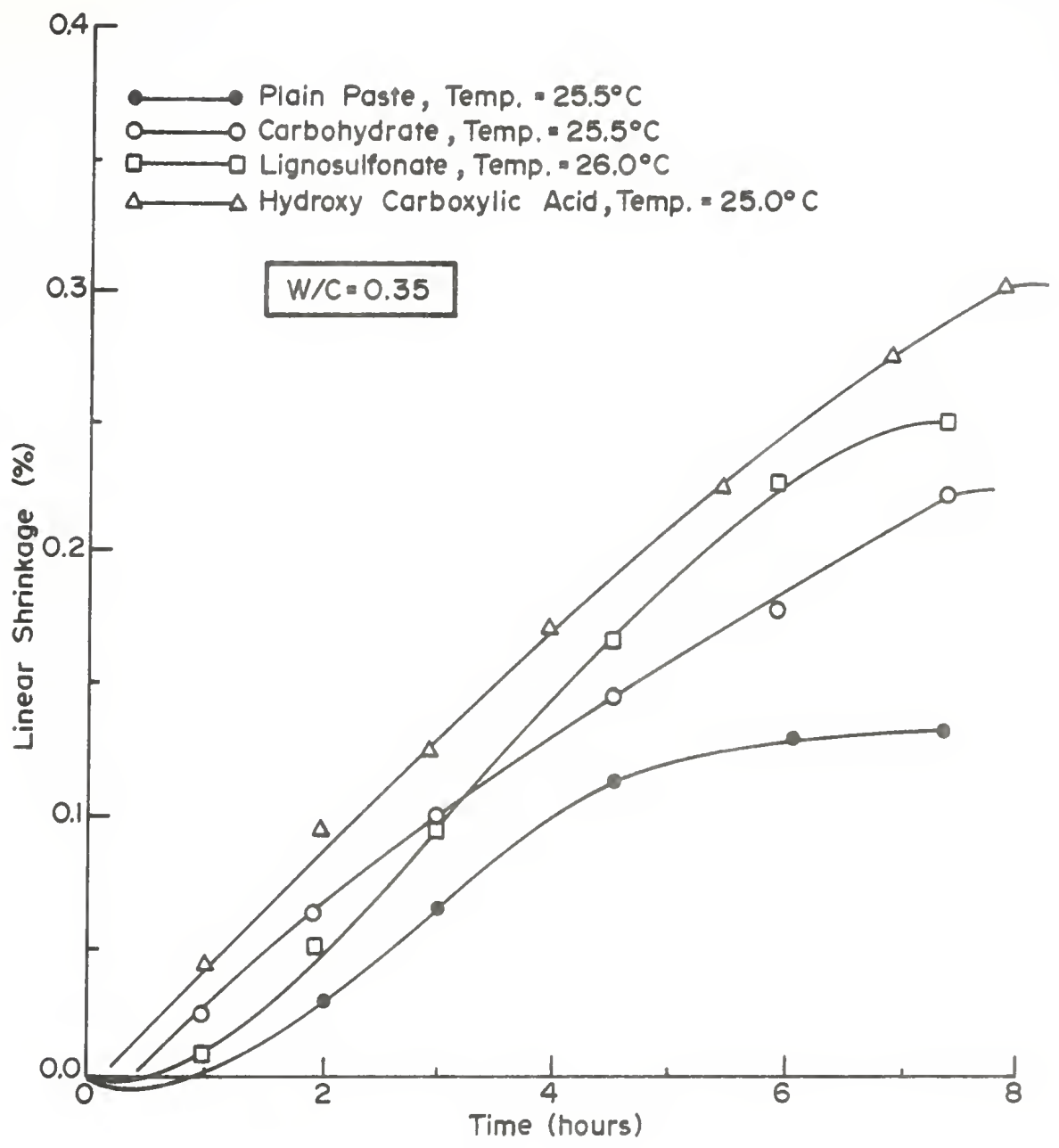

FIGURE 10 -COMPARISON OF SHRINKAGES AT $75 \%$ RELATIVE HUMIOITY. 
shrinkage is observed for pastes made with efther I1gnosulfonate or carbohydrate retarders.

Figures $11,12,13$ and 14 show the linear shrinkage versus time for plain paste and paste with retarding admixtures.

\section{Analysis of Varfance}

An analysis of variance was conducted on the results of the equilibrium shrinkages of plain paste and paste with retarding admixtures, in an effort to test whether they significantly differ or not at the one percent level. The ' $F$ ' test, or varfance rat1o test, was used to make comparisons. Contrasts were constructed, pla1n paste versus paste with each retarding admixture, and within a particular type, for experiments at one relative humflty versus the other.

Equilibrium shrinkages are tabulated in the Table 18. The equilibrium shrinkages are those existing when the change in shrinkage becomes negliglble. The 'F' rattos for the comparisons between plain paste and pastes with different types of retarding admixtures are tabulated in the Table 19. Table 19 also shows the 'F' ratios for comparisons at dfferent relative humldities.

For the equilibrium shrinkage of plain paste compared with that of different type of retarding admixtures, the ' $F$ ' ratios are significantly different at the one percent level. Th1s is true at all relative humflties, except for plain paste versus 11 gnosulfonate at 


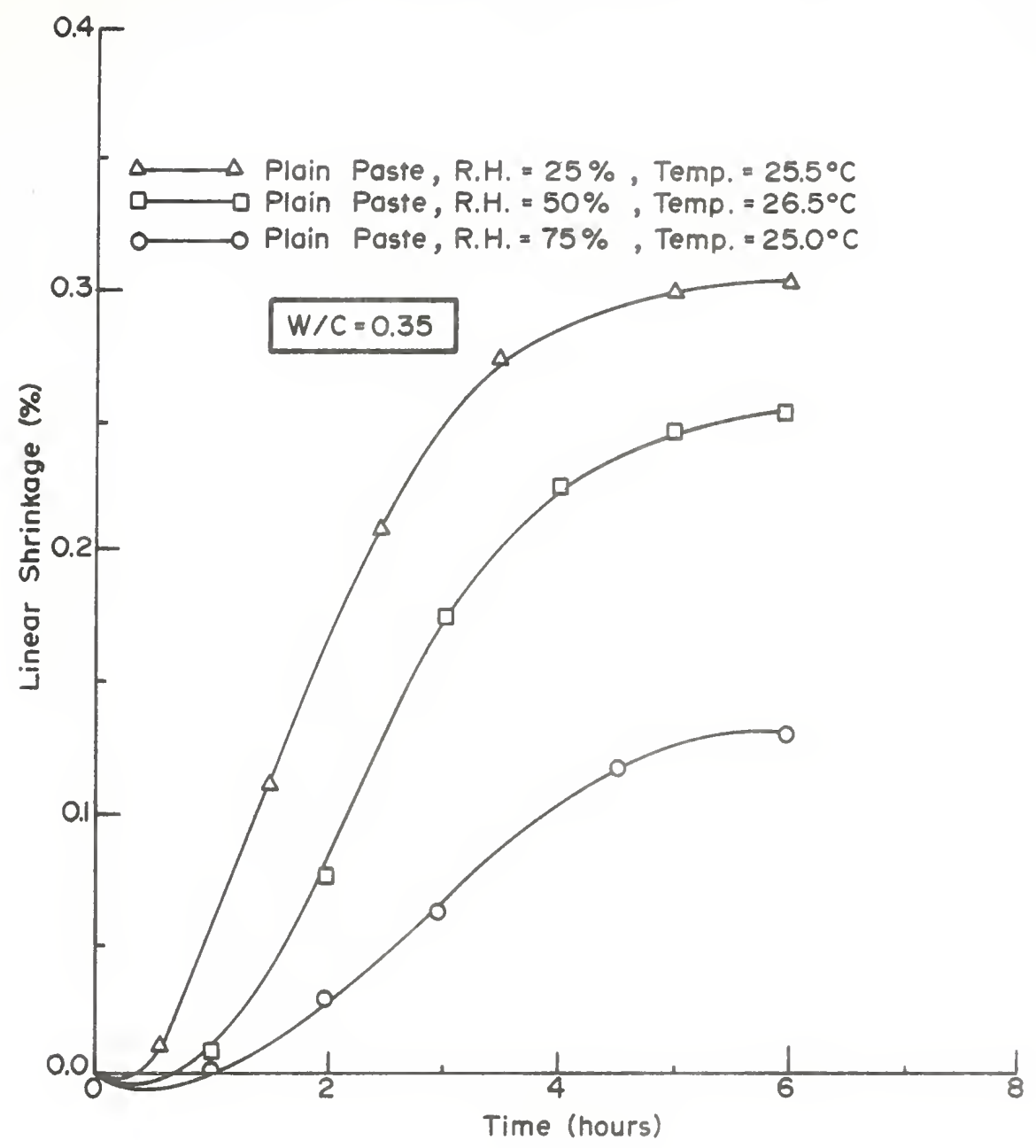

FIGURE II - SHRINKAGE CURVES FOR PLAIN PASTE. 


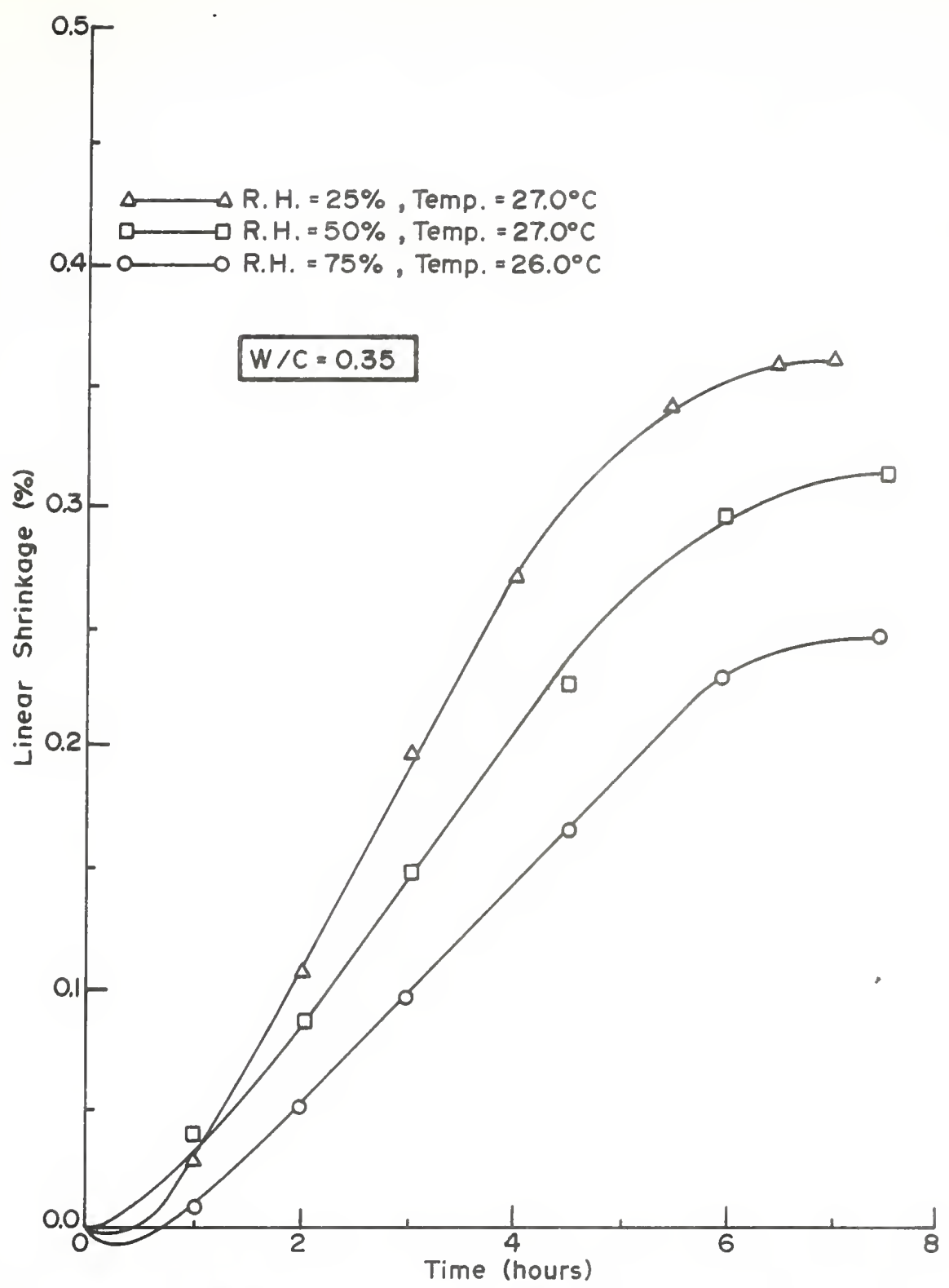

FIGURE I2 - SHRINKAGE CURVES USING (L), LIGNOSULFONATE. 


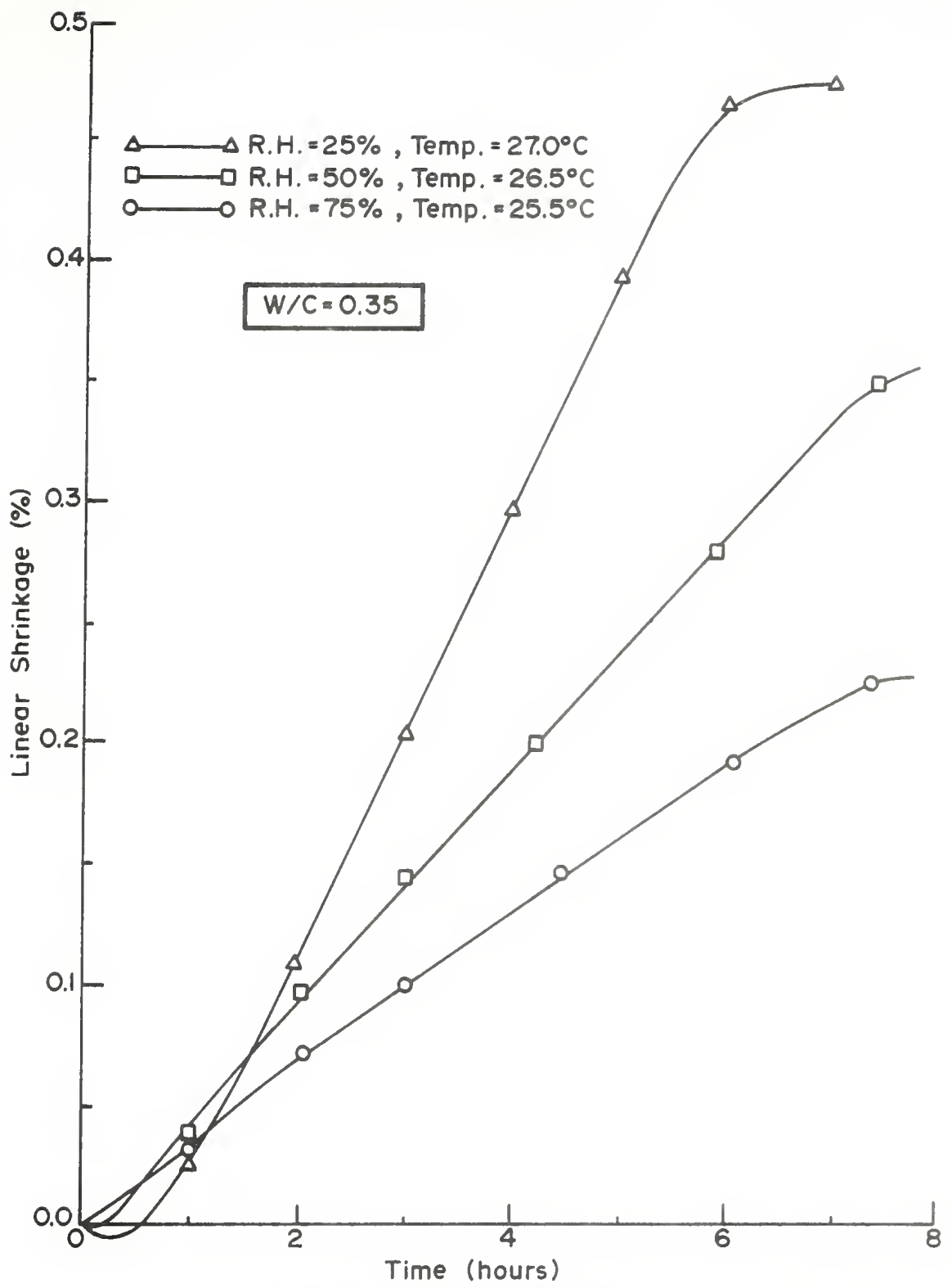

FIGURE I3-SHRINKAGE CURVES USING (S), CARBOHYDRATE. 


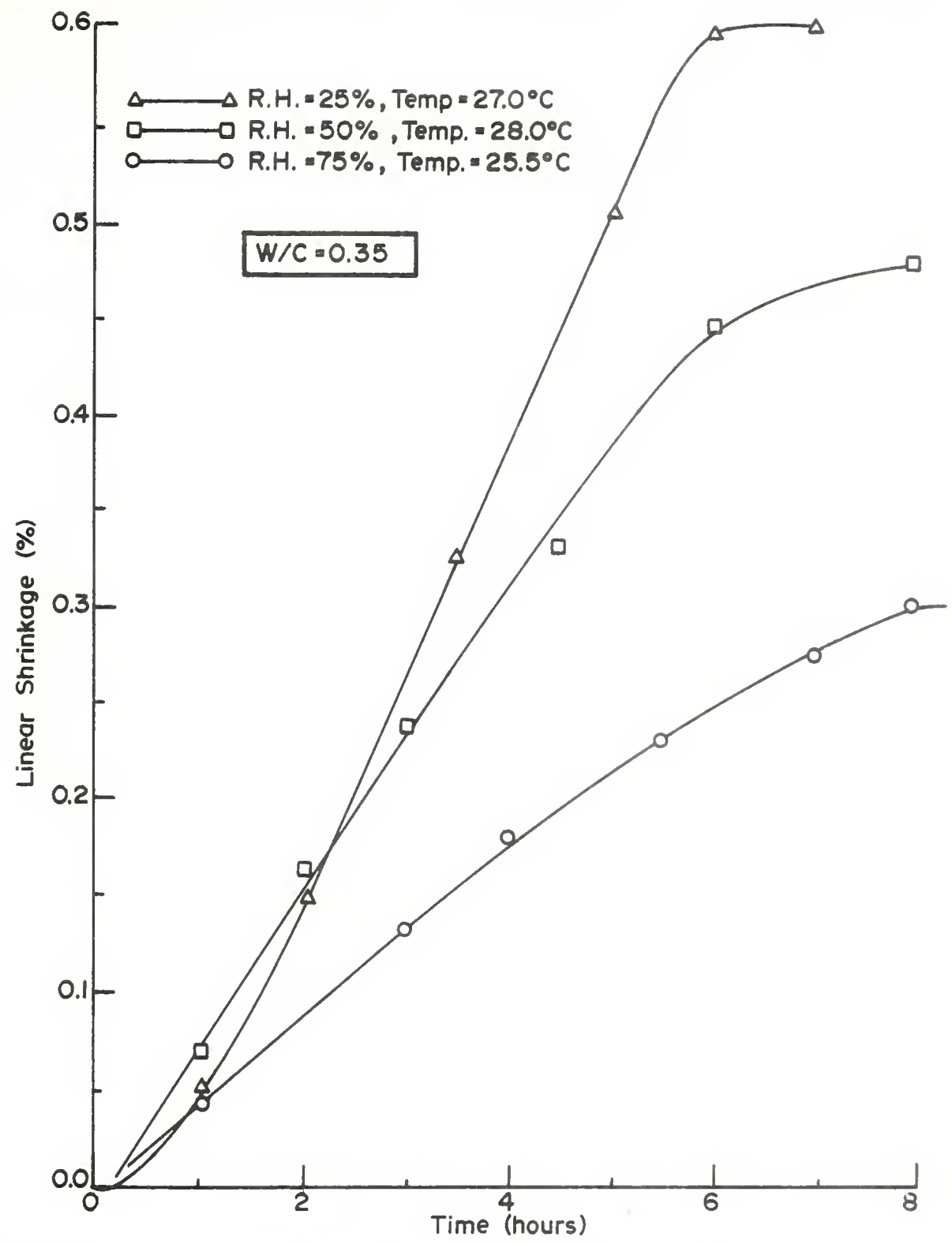

FIGURE 14 -SHRINKAGE CURVES USING (A), HYDROXY CARBOXYLIC ACID. 
TABLE 18 EQUILIBRIUM SHRINKAGES

(mi111onths)

\begin{tabular}{lcccc}
\hline R.H. & Plain Paste & $\begin{array}{c}\text { Paste with } \\
\text { Lignosulfonate }\end{array}$ & $\begin{array}{c}\text { Paste with } \\
\text { Carbohydrate }\end{array}$ & $\begin{array}{c}\text { Paste wydroxycar- } \\
\text { boxylic Ac1d } \\
\text { boxich }\end{array}$ \\
\hline $25 \%$ & 3051 & 3644 & 4916 & 6187 \\
& 2967 & 3560 & 4746 & 5848 \\
\hline $50 \%$ & 2542 & 3221 & 3644 & 4746 \\
\hline $75 \%$ & 3136 & 3644 & 4831 \\
\hline & 1356 & 2543 & 2204 & 3136 \\
\hline
\end{tabular}




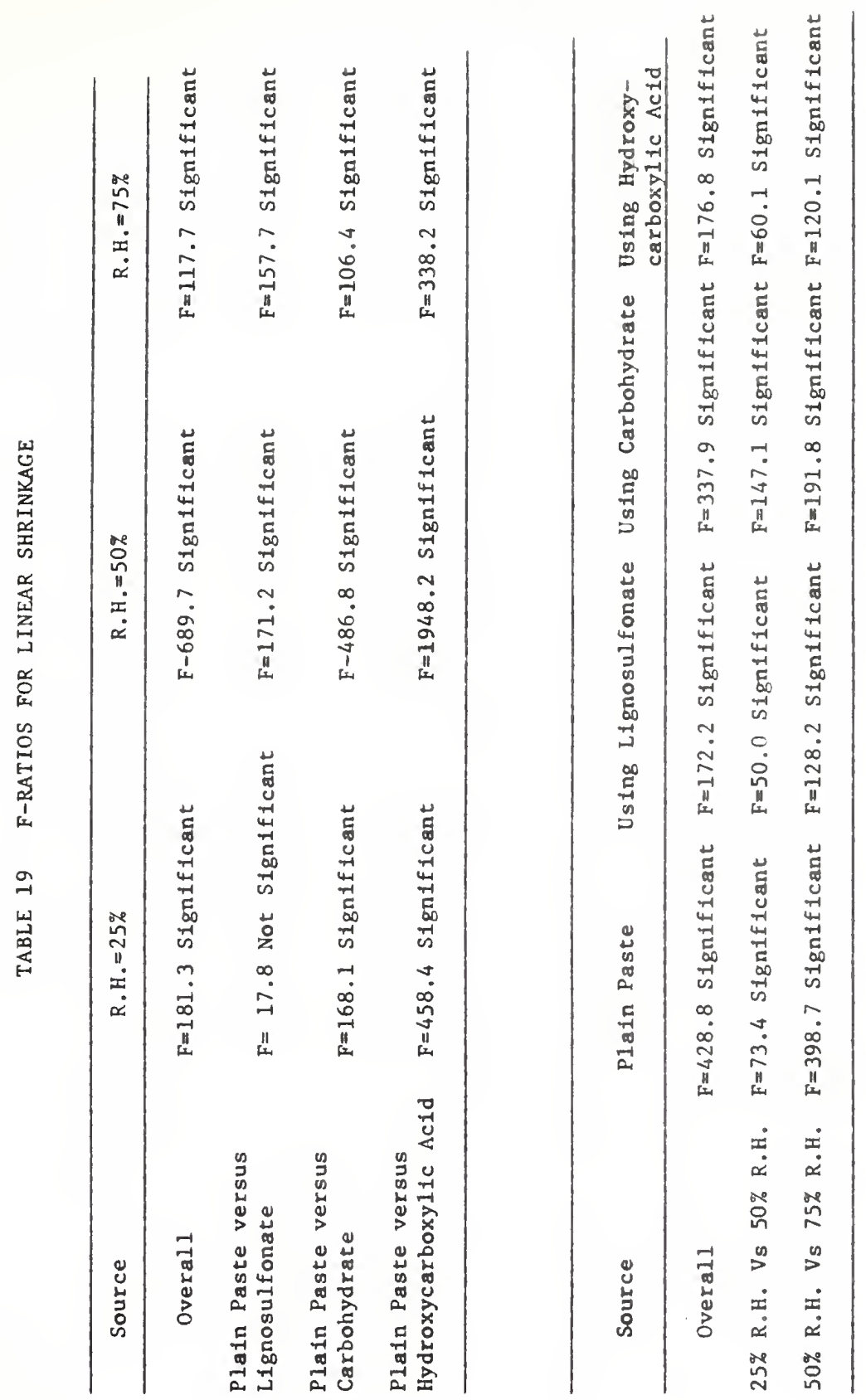


25 percent relative humidity. As expected, the ' $F$ ' ratios are significently different for each of the types when compared at different relative humidities.

An anelysis of varlance was also conducted for the slopes of the curves in the region where the rate of shrinkage was considerable. The slopes of each curve was calculated by fitting a stralght line using the method of least squares for the region where the rate of shrinkage was considerable. Then the same k1nd of procedure was followed as explained before.

The slopes are tabulated in the Table 20 for plaln paste and pastes with retarding admixtures at different relative humidities. The ' $F$ ' rat1os are tabuleted in Table 21. As expected, the ' $F$ ' rat10s are significantly different within each type for comparisons at different relative humidities except for the comparison of plain paste at 25 percent relative humldity versus plain paste at 50 percent relative humflity. The ' $F$ ' ratlos of the slopes of the stralght line regions are compared for plain paste and pastes with retarding admixtures at different relative humidities. 
TABLE 20 SLOPES $^{*}$ IN THE STRAIGHT LINE PORTION

\begin{tabular}{|c|c|c|c|c|}
\hline R.H. & Plain Paste & $\begin{array}{c}\text { Paste with } \\
\text { Lignosulfonate }\end{array}$ & $\begin{array}{l}\text { Paste with } \\
\text { Carbohydrate }\end{array}$ & $\begin{array}{c}\text { Paste with } \\
\text { Hydroxycarboxyl1c } \\
\text { Acld }\end{array}$ \\
\hline \multirow{2}{*}{$25 \%$} & 822.1 & 709.9 & 944.3 & 1021.6 \\
\hline & 889.8 & 723.8 & 922.5 & 959.5 \\
\hline \multirow{2}{*}{$50 \%$} & 711.1 & 547.1 & 468.6 & 725.7 \\
\hline & 745.7 & 527.3 & 490.9 & 750.6 \\
\hline \multirow{2}{*}{$75 \%$} & 339.1 & 429.1 & 303.5 & 400.3 \\
\hline & 318.4 & 467.8 & 315.9 & 361.1 \\
\hline
\end{tabular}

* Slope $=\frac{\text { Difference of Shrinkages in m11110nths }}{\text { Difference of times in hours }}$ 


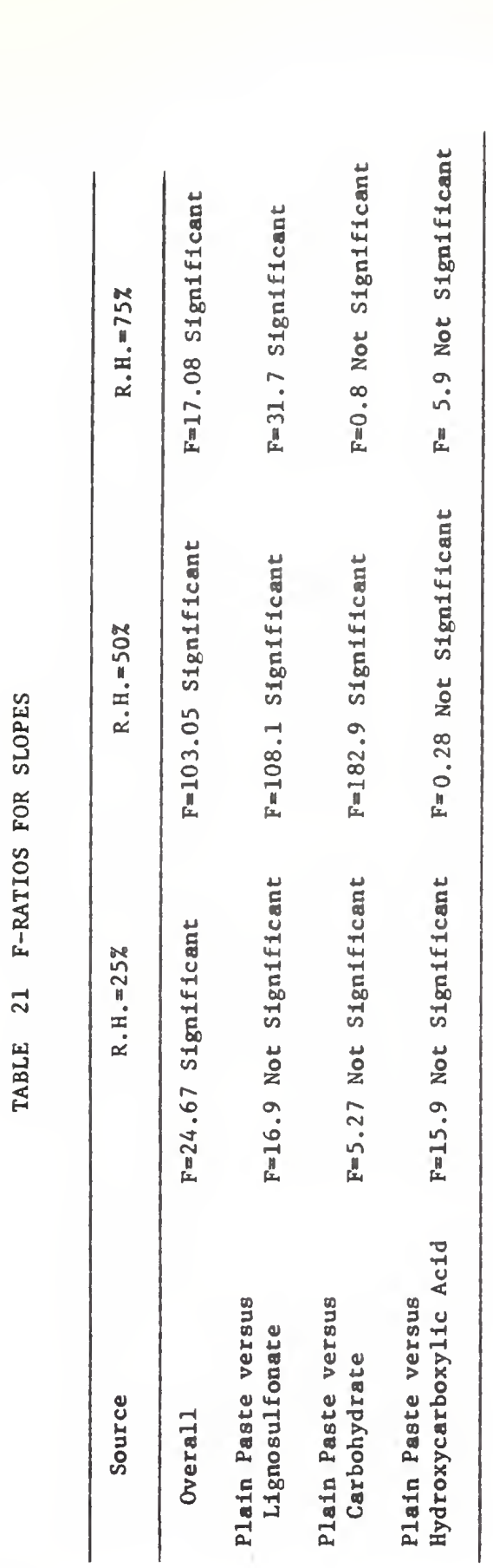


DISCUSSION

\section{Plast1c Shrinkage}

Figures 8, 9 and 10 show linear plastic shrinkages in percent for the plain paste and pastes with retarding admixtures at three different relative humidities. At the three different relative humldities, the plastic shrinkages measured for pastes with retardIng admixtures are higher than plastic shrinkage for the plain paste. An Inttial expansion, followed by rapid contraction was measured In all the cases. Th1s Inttial expansion was probably due to the formation of ettringite in the paste.

Figure 9 shows that transitlons from rapid plastic shrinkage to slow shrlnkage were different for different pastes. This transition for plain paste occurs at about 4 hours, and for pastes with retarding admixtures at about 6 hours after the commencement of the experfment. The Vicat Inftial setting times for the plain paste and pastes with retarding admixtures are $3 \frac{1}{2}$ hours and 6 hours respectively, except that the paste made with hydroxscarboxylic acid retarder has an earlier Inltial setting time than the other admixtures. When retarding admixtures were used, it was very difficult to locate the transition between rapld shrinkage and slow shrinkage so the stated tranaltion may be off by one hour from the above stated value ( 6 hours) depending on ones interpretation of the curve. 
It 1s recalled that the dosages of reterding admixtures usad were the dosages required for fifty percent retardation determined by the penetration resiotance teat. Th1s test was carried out with mortar of water cement rat10 0.50 by weight. In contrast, the Vicat Inftial setting times were determined for pastes with water cement rat10 0.35 by we1ght. It was observed that in determining the Vicat inftal setting times and in casting spectmens in the ahrinkage experimenta, the amount of bleeding water avallable to evaporate from the surface when hydroxycarboxylic acld was used, was much greater than that with the other two types of retarding admixtures and for plain paste. In consequence of the high rate of bleeding a lower affective water cement ratio regulted, hence reducing the inftial setting time compared with the other two types of retarding adm1xtures. The above discussion is not necessarily true in a penetration resistance test on a larger specimen such as used for the penetration tests by Yamamoto as previously mentioned. The plastic shrinkages for the pastes with carbohydrate and 11gnosulfonate were higher than the plast1c shrinkage for the pla1n paste. Th1s apparently was due to the increased time in which these pastes were in the plastic atage. Rates of shrinkage (slopes) for pastes with 11 gnosulfonate and carbohydrate differ significantly from the rate of shrinkage of plain paste. When ilgnosulfonate or carbohydrate was used, it was observed that 1 ess bleeding occurred than for plain paste. 
The plastic shrinkage for paste with hydroxycarboxylic acid retarder was higher then the plastic shrinkages of the other two types of retarders. Also as seen in Figure 9, the rate of shrinkage with hydroxycarboxylic actd retarder was higher than the rate of shrinkages of the other two types of retarders. This was accompanied by an observed high rate of bleeding. High rates of shrinkage were therefore assoclated with the bleeding of plain paste and pastes with type $D$ admixtures which exh1bited bleeding. Referring to the results of the analysis of variance, Table 19, the above discussion, 1.e. admixtures cause greater ahrinkages, was shown true at all relative humidities except for plain paste versus 11gnosulfonate at 25 percent relative humidity. In the case of 11gnosulfonate 1 was not significantly different from plain paste at the 25 percent relative humidity yet it was significant at both 50 and 75 percent humidit1es. Further comparison of 1 t 8 performance shows that it was less sensitive to humidity conditions. For example referring to Figure 10 , at 75 percent relative humddity 11gnosulfonate paste is second highest in shrinkage. Yet at 25 percent relative humidity, see Figure 8 , it is only slightly higher than plain paste (and not statically different) while other admixtures have a much greater increase in shrinkage at the lower relative humidity. This indicates that under variable conditions of humidity, such as experlenced in fleld concreting practice, lignosulfonate admixture w1ll produce a more unfform product with respect to plastic shrinkage. 
Paste with retarding admixtures gave higher shrinkages than the plain paste. This was in part due to the retardation in setting t1me. An experimental run was conducted w1th calcium chloride (2 percent by we1ght of cement) as an accelerator at each of the three humidities to reduce the setting below that of plain paste. Due to the decreased time in which the paste was in the plastlc stage, the plastic shrinkage was expected to be less than for plain paste. The results show, in Figure 18 (Append1x), when compared to the plain paste of Figure 11, that this did in fact occur. However, the rate of shrinkage (slope) obvlously 18 greatest for the calc1um chloride. Th1s also is evident in F1gure 19. For the condition measured calclum chloride resulted in decreased total plastic shrinkage.

F1gure 19 (Append1x) shows the plot of Inear shrinkage open to the laboratory atmosphere. Under this condition shrinkages were greater as compared with controlled relative humldty conditions. The relative humldity of the laboratory was approximately 50 percent. It was suspected that the rate of evaporation in an open atmosphere was h1gher than the rate of evaporation in controlled relative humidity condition. When the rate of evaporation was more, the water avallable for hydration process might be less. Since the degree of hydration was known to be directly related to nonevaporable water of the paste, nonevaporable water determinations were made. The samples were taken after 8 hours of casting both from the open atmosphere and from the controlled 50 percent relative hum1dity 
condition. The samples were vacuum oven dried for 36 hours and tests were run for nonevaporable water determination. It was found that the content of nonevaporable water in the paste was less when the experiment was run in an open condition than 1 was with the 50 percent controlled relative humidity (see Appendix Table 36 for nonevaporable water content).

One experiment was run passing laboratory afr over the spec1men directly. The laboratory relative humldity varled from 59 per cent at the beginning of the experiment to 51 percent at the end of the experiment. The readings are tabulated in the Appendix Table 37. From this it was concluded that in an open condition more shrinkage occurred due solely to the greater evaporation rate. Consideration of carbonation shrinkage was eliminated when closed atmosphere tests showed no difference when the alr had been passed through Mallcosorb, an Indicating carbon dloxide absorbent. Since a small chamber was used to contain the experimental samples and the alr was passed slowly through the chamber, entering and exiting at locations, about one inch above the sample, diffusion process was presumably taking place between the sample and flow of alr. Th1s was, of course, reflected by the incrcased shrinkages at lower hum1dities. One may recall that the humidity at the downstream end of the chamber was verifled by humidity sensor and not found to differ from that expected from the acid bath system. However, it is belleved that the open atmosphere reaulted in air currents causing a greater rate of evaporation than occurred in the controlled condition. The discrepancy between open atmosphere and controlled 
condition results did not Invalidate the results insofar as comparing the different admixtures. It should be recognized, however, that natural exposures of cement paste to atmosphere w111 probsbly result in shrinkage greater than those reported for the same relative humidity in the controlled experiment.

The practical applications of this work are for concrete not for paste hence absolute shrinkage values are not relevent but the relative shrinkage 1.e. those of different admixtures are relevent to concrete construction.

\section{Plastic Shrinkage Cracking}

In an effort to explain the mechanism of plastic shrinkage crack1ng, some facts concerning the inftial hydration process need to be revlewed brlefly.

Tricalcium silicate and tricalcium aluminate are considered to be the princlpal active components of portland cement at early stages of hydration. When tricalcium silicate reacts with water, calcium sllicate hydrate 18 formed and lime is released Into solution. On the other hand, tricalcium aluminate reacts with sulfate and calclum Ions, from the solution to form ettringite.

In a heat evolution curve of cement hydration, an inftial rapld heat evolution occurs, when the cement and water brought into contact (18). The Inftial rapid hydration 18 followed by a dormant perfod which is due to the formation of a sulfoaluminate coating on the highly reactive tricalcium aluminate phase and inftially formed calclum sllicate hydrate gel on the tricalclum sllicate phase. 
A second peak, due to the continued hydration of the tricslclum aluminate and mainly due to additional hydration of tricalcium sillcate, occurs at the end of dormant perfod, which 1 s perhaps a couple of hours long. According to Verbeck (18), the inftisl setting time of cement paste lies after the end of the dormant period and before the point of maximum peak of the second heat generation. Powers(19), considered that the end of dormant perfod and the beginning of the second heat evolution peak, 1s due to break up of the coating of the hydration products that would allow an Increase in the rate of hydration to take place. The breakup such as this coating, is attributed to the generation of an osmotic pressure caused by the difference of concentration between the bulk aqueous phase and anhydrous cement minerals. Indeed if the dormant perlod 1s caused by such a coating, at least a partial break up of the coating is necessary for an increase in the hydration. The heat evolution rate declines after the second peak; Powers (19) has discussed the detalls of the processes taking place here.

Lerch (4) reported that the plastlc shrinkage cracks may develop when rate of evaporation exceeds the rate at which bleeding water rises to the surfaca causing the disappearance of the sheen from the surface. According to Ravina and Shalon (5), the appearance of the firat plastic ahrinkage crack consistently colncided with the transition from rapid shrinkage to the slow rate one. The reason given for this transition is the changes in the flow properties of the mortar, which in turn depend on the rate of hydration. 
In the present work, It was observed that the appearance of plast1c shrinkage cracks consistently colnclded with the transition from rapld shrinkage to the slow rate one. This transition 1 iss somewhere near the initial setting time of the cement paste. According to Verbeck (18), this initial setting time lies somewhere In between the end of dormant period and the maximum peak of the second heat of evolution. Up to the inftial setting time, the sheen exists due to the low heat evolution in the dormant period which causes less rate of evaporation. As soon as dormant perfod is over the rate of heat evolution increases rapidly and evaporation is speeded up, and the disappearance of sheen from the surface occur. From the above discussion it should be noted that the disappearance of sheen from the surface is due to the increased rate of hydration snd rate of evaporation.

Figures 15 and 16 show the specimans at 25 and 50 percent relative humidities. Comparing plain paste specimens in Figures 15 and 16 , the number of cracks formed at 25 percent relative humidity is larger than the number of cracks formed at 50 percent relative humidity, as would be expected. This is true with all three retarding admixtures as well. The number of cracks formed in plain paste and pastes with retarding admixtures are more or 1 ess proportional to their plastic shrinkage. With hydroxycarboxylic actd retarder, the cracks are greater in number. F1gure 17 (Append1x) shows the specimens at laboratory atmosphere. It can be seen that more cracks occurred due to greater shrinkage of the paste. 


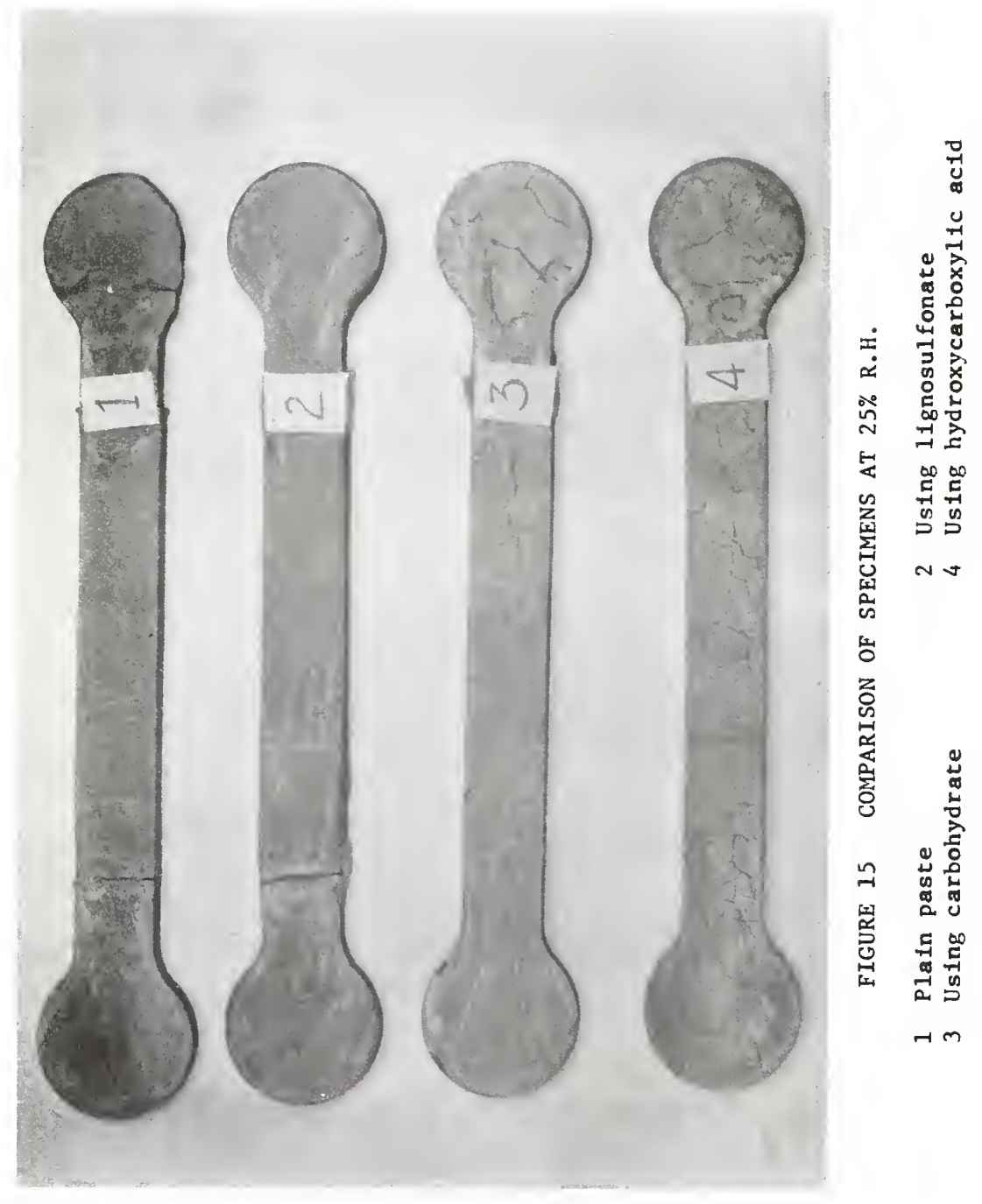




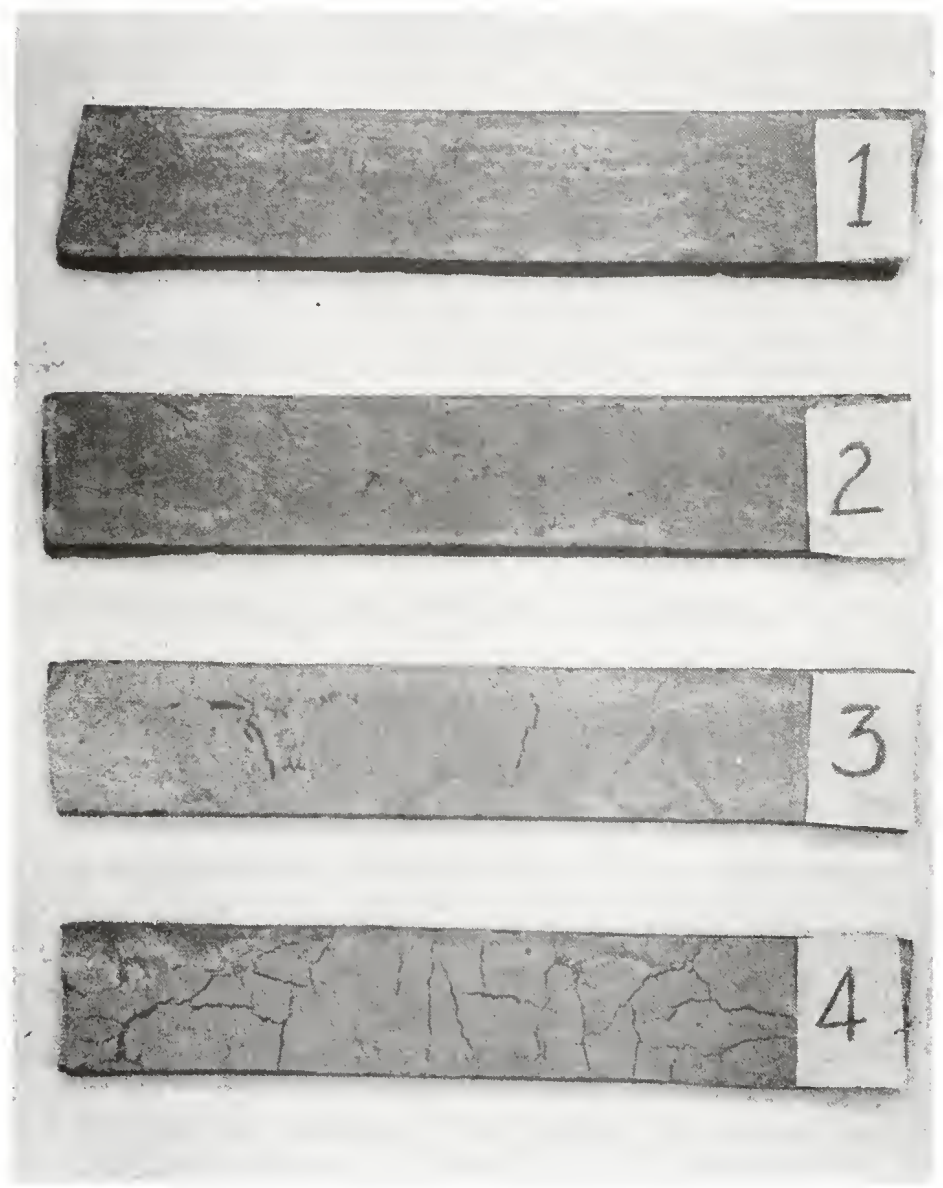

FIGURE 16 COMPARISON OF SPECIMENS AT 50\% R.H.

1 Plain paste

2 Using lignosulfonate

3 Using carbohydrate

4 Using hydroxycarboxylic acid 
CONCLUSIONS

Based on the measurements of plastic ahrinkage of specimens, the following conclustons seems to be reasonable. They apply only to the particular composition of cement used, condition and set up of the experiment.

1. Using retarding admixtures, plastic shrinkage is higher than the plastic shrinkage of plain paste. The higher shrinkage 1s due to the increased perlod of time spent in the plastic stage and, with some retarders, an increase in the amount of bleeding water.

2. The appearance of the first crack colncides with transition from a high inftial rate of shrinkage to a slower rate. Since this transition approximately colncides with Vicat initial setting time, the rate of hydration and the rate of evaporation influence crack formation.

3. The rate of shrinkage varies for different admixtures when the relstive humidity changes. Th1s results in lignosulfonate giving the most unfform amount of shrinkage at different relative humidities.

4. The morphology of the plastic cement paste is apparently different for different admixtures are evidenced by difference in the bleeding and in rate of shrinkage. 
LIST OF REFERENCES 


\section{LIST OF REFERENCES}

(1) Standard Speciflcat1ons, Indlana State H1ghway, 1969.

(2) G. Pickett, "Effect of Aggregate on Shrinkage of Concrete and Hypothesis concerning Shrinkage" PCA Bulletin No. 66, Feb. 1956.

(3) ASTM Standards, Part 10, 1971.

(4) W. Lerch, "Plastic Shrinkage" ACI Journal, Feb. 1957, No. 8, Vol. 28, pp. 797-802.

(5) D. Ravina and R. Shalon, "Plastic Shrinkage Cracking" ACI Journal Vol. 65, April 1968, pp. 282-292.

(6) M. Spindel, Discussion of the paper by W. Lerch, "Plastic Shrinkage" ACI Journal Vol. 29, Dec. 1957, pp. 1343-1344.

(7) F. 0. Slate and R. E. Matheus, "Volume Changes on Setting and Curing of Cement Paste and Concrete from Zero to Seven Days" ACI Journal, Vol. 64, Jan. 1967, pp. 34-39.

(8) del Campo, M, "A New Method to Study the Early Volume on the Neat Cement Paste" RILEM Bulletin No. 4, Oct. 1959, pp. 18.

(9) E. A. Abdun-Nur, D1scussion of the paper by W. Lerch, "Plast1c Shrinkage" ACI Journal Vol. 29, Dec. 1957, pp. 1341.

(10) F. D. Beresford and F. A. Blakey, Discussion of the paper, "Plast1c Shrinkage" ACI Journal Vol. 29, Dec. 1957, PP. 1342.

(11) L. H. Tuth1ll, Discussion of the paper "Plast1c Shrinkage" ACI Journal Vo1. 29, Dec. 1957, Pp. 1344-1345.

(12) "Admixtures in Concrete" Speclal Report 119, H1ghway Research Board.

(13) "Admixtures for Concrete" Report of ACI Comm1ttee 212, ACI Journal Vol. 60, Nov. 1963, PP. 1481-1524.

(14) "Cement and Concrete Terminology" by ACI Committee 116 Sp-19. 
(15) D.M.F. Orr, MAI, MICE, MIEAust and G. F. Halgh, "An Apparatus for Measur1ng the Shr1nkage Charactaristics of PIastic Mortars" Magazine of Concrete Research, Vo1. 23, No. 74, March 1971, pp. 43-50.

(16) R. E. Cromarty, and J. G. Bryden, "An Apparstus for Measuring Dimensionsl Changes in Fresh Paste" Magazine of Concrete Research, Vol. 19, No. 61, Dec. 1967, pp. 239-242.

(17) Y. Yamamoto, "Retarders for Concrete, and The1r Effects on Setting Time and Shrinkage" Thesis for Ph. D., Purdue University, Lafayet te

(18) G. Verbeck, "Cement Hydration Reactions at Early Ages" Research Department Bulletin No. 189, PCA.

(19) T. C. Powers, "Some Physical Aspects of the Hydration of Portland Cement" Journal of the PCA Research and Development Laboratorles, No. 3, Vol. 1, Jan. 1961, pp. 47-56. 
APPENDIX 

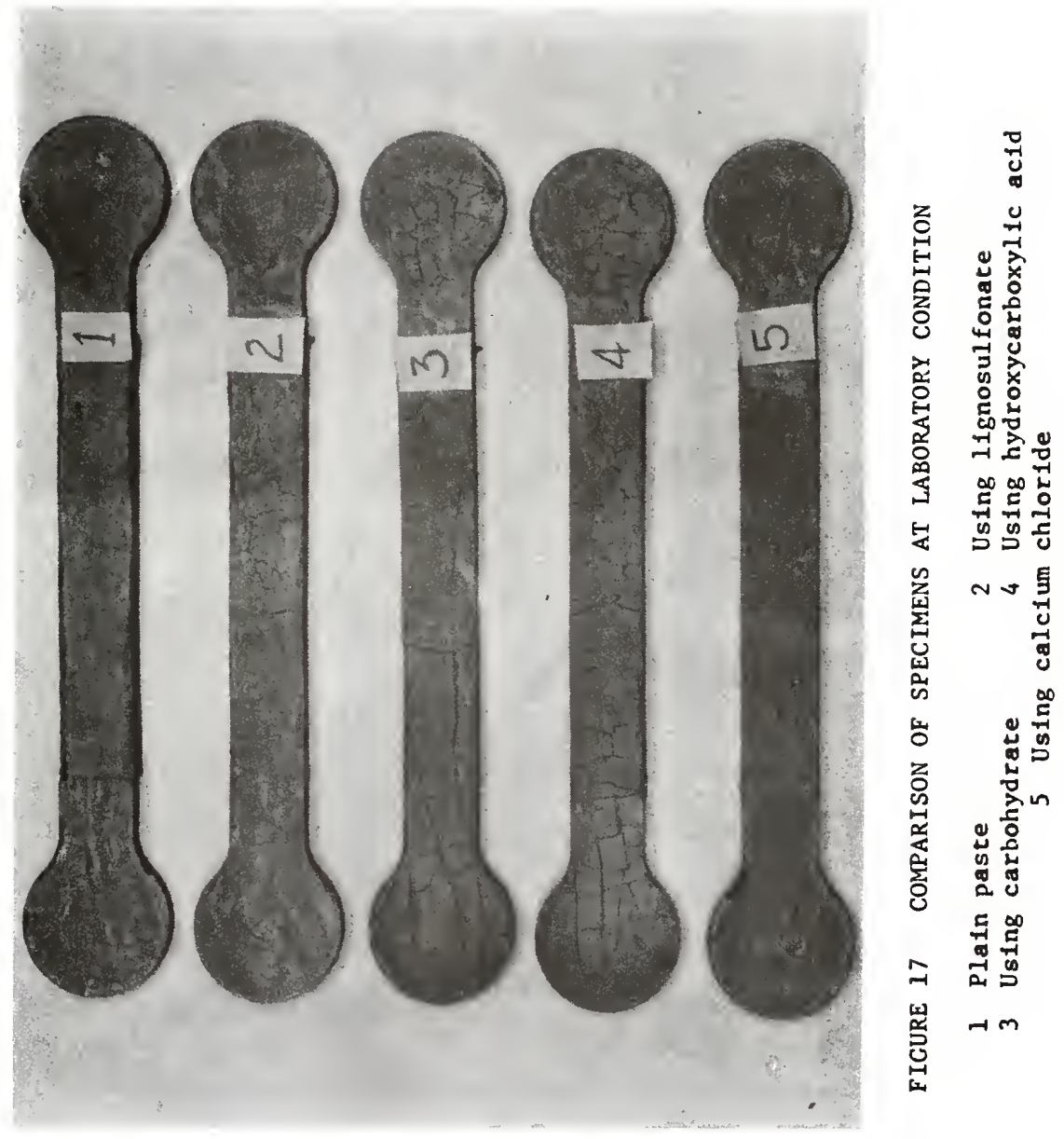


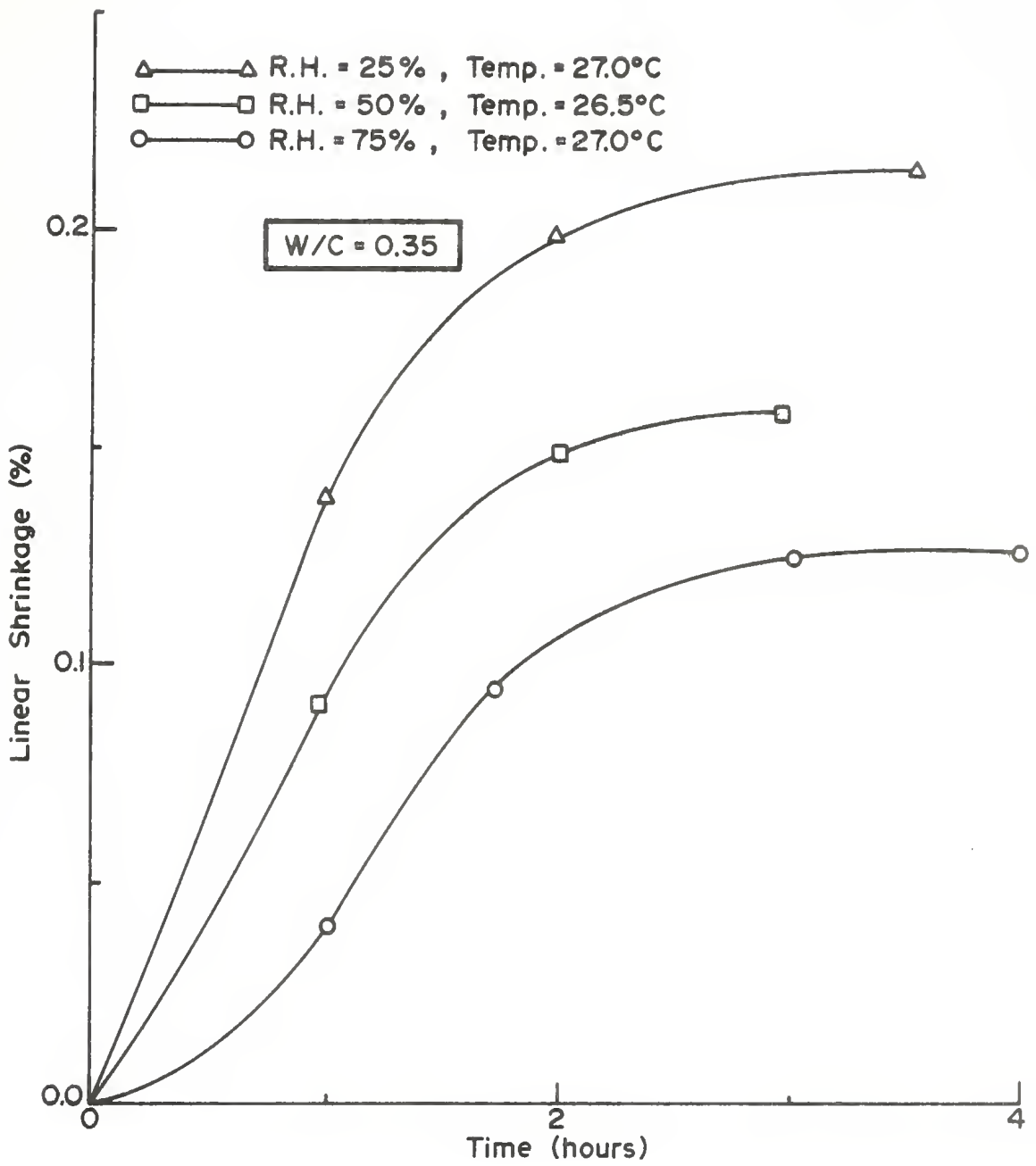

FIGURE 18 -SHRINKAGE CURVES USING CALCIUM CHLORIDE. 


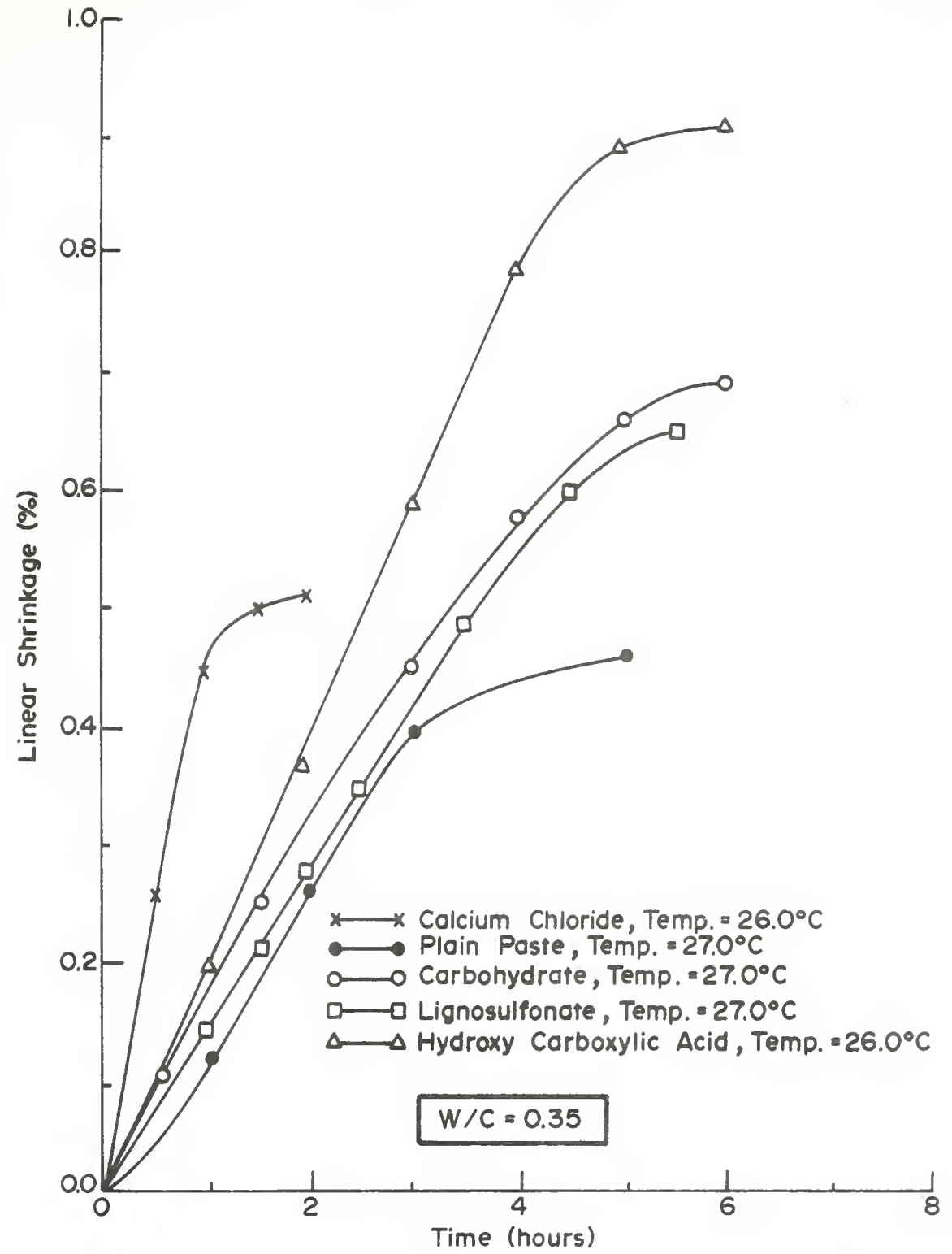

FIGURE 19 - COMPARISON OF SHRINKAGE AT LABORATORY
ATMOSPHERE. 
TABLE 22 COMPARISON OF SHRINKAGES AT 25\% R.H.

Water Cement Ratio: $\quad .35 \quad$ Relative Hum1d1ty: 25.1

DATA

\begin{tabular}{lcccc}
\hline \multicolumn{5}{c}{ Groups } \\
\hline & Plain Paste & Lignosulfonate & \\
\hline & 3051 & 3644 & 3 \\
Observations & 2967 & 3560 & 4916 & 4 \\
& 6018 & 7204 & 4746 & 6187 \\
\hline Total & 3009 & 3602 & 9662 & 5848 \\
\hline Mean & & 4831 & 6017 \\
\hline
\end{tabular}

$C_{1}=$ Contrast: Plain Paste Vs Lignosulfonate

$\mathrm{C}_{2}=$ Contrast: Plain Paste Vs Carbohydrate

$\mathrm{C}_{3}=$ Contrast: Plain Paste Vs Hydroxy Carboxyl1c Acid

ANALYSIS OF VARIANCE TABLE

\begin{tabular}{lcrrr}
\hline Source & $\begin{array}{c}\text { Deg. of } \\
\text { Freedom }\end{array}$ & $\begin{array}{c}\text { Sum of } \\
\text { Squares }\end{array}$ & \multicolumn{1}{c}{$\begin{array}{c}\text { Mean } \\
\text { Squares }\end{array}$} & F-Rat10 \\
\hline Among Groups & 3 & 10737634.3 & 3579211.4 & 181.3 \\
Contrast $C_{1}$ & 1 & 351669.0 & 351669.0 & 17.8 \\
Contrast C & 1 & 3319684.0 & 3319684.0 & 168.1 \\
Contrast C 3 & 1 & 9051072.2 & 9051072.2 & 458.4 \\
W1th1n Groups & 4 & 78966.5 & 19741.6 & \\
\hline Total Corrected & 7 & 10816600.8 & & \\
\hline
\end{tabular}

$\mathrm{F}_{.01,3,4}=16.7$

$F_{01,1,4}=21.2$ 
TABLE 23 COMPARISON OF SHRINKAGES AT 50\% R.H.

Water Cement Rat10: .35 Relative Hum1d1ty: 50\%

DATA

\begin{tabular}{lcccc}
\hline & \multicolumn{4}{c}{ Groups } \\
\hline & $\begin{array}{l}1 \\
\text { Plain Paste }\end{array}$ & $\begin{array}{c}\text { Lignosulfonate Carbohydrate } \\
\text { Hydroxy } \\
\text { Carboxyl1c Ac1d }\end{array}$ \\
\hline \multirow{2}{*}{ Observations } & 2542 & 3221 & 3644 & 4746 \\
\hline Totsl & 2458 & 3136 & 3644 & 4831 \\
\hline Mean & 5000 & 6357 & 7288 & 9577 \\
\hline
\end{tabular}

$C_{1}=$ Contrast: Plaln Paste Vs Lignosulfonate

$\mathrm{C}_{2}$ = Contrast: Plain Paste Vs Carbohydrate

$\mathrm{C}_{3}$ - Contrs8t: Pla1n Paste Vs Hydroxy Carboxyl1c Acld

ANALYSIS OF VARIANCE TABLE

\begin{tabular}{lcccc}
\hline Source & $\begin{array}{l}\text { Deg. of } \\
\text { Freedom }\end{array}$ & $\begin{array}{l}\text { Sum of } \\
\text { Squares }\end{array}$ & $\begin{array}{c}\text { Mean } \\
\text { Squares }\end{array}$ & F-Ratio \\
\hline Among Groups & 3 & 5562500.5 & 1854166.8 & 689.7 \\
Contrast $C_{1}$ & 1 & 460362.2 & 460362.2 & 171.2 \\
Contrast $C_{2}$ & 1 & 1308736.0 & 1308736.0 & 486.8 \\
Contrast $C_{3}$ & 1 & 5237232.2 & 5237232.2 & 1948.2 \\
With1n Groups & 4 & 10753.0 & 2688.2 & \\
\hline Total Corrected & 7 & 5573253.5 & & \\
\hline F.01,3,4 $=16.7$ & & & F $01,3,4=21.2$
\end{tabular}


TABLE 24 - COMPARISON OF SHRINKAGES AT 75\% R.H. Water Cement Rat1o: 0.35 Relative Humldity: $75 \%$ DATA

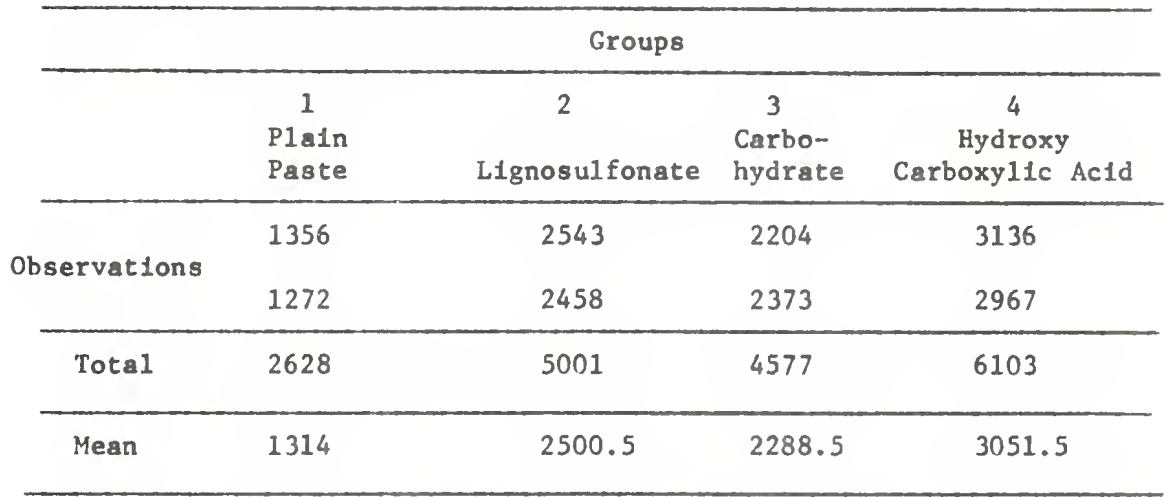

$\mathrm{C}_{1}=$ Contrast: Pla1n Paste Vs L1gnosulfonate

$\mathrm{C}_{2}=$ Contrast: Pla1n Paste Vs Carbohydrate

$\mathrm{C}_{3}=$ Contrast: Plain Paste Vs Hydroxy Carboxylic acid

ANALYSIS OF VARIANCE TABLE

\begin{tabular}{lcccc}
\hline Source & $\begin{array}{c}\text { Deg. of } \\
\text { Freedon }\end{array}$ & $\begin{array}{c}\text { Sum of } \\
\text { Squares }\end{array}$ & $\begin{array}{c}\text { Mean } \\
\text { Square }\end{array}$ & F-Rat1o \\
\hline Among Groups & 3 & 3153526.3 & 1051175.4 & 117.7 \\
Contrast $C_{1}$ & 1 & 1407782.2 & 1407782.2 & 157.7 \\
Contrast $C_{2}$ & 1 & 949650.2 & 949650.2 & 106.4 \\
Contrast $C_{3}$ & 1 & 3018906.2 & 3018906.2 & 338.2 \\
W1thin Groups & 4 & & 8925.3 & \\
\hline Total Corrected & 7 & 3189227.8 & & \\
\hline
\end{tabular}
$F_{.01,3,4=16.7}$
$\mathrm{F}_{.01,1,4}=21.2$ 
TABLE 25 SHRINKAGES FOR PLAIN PASTE

Water Cement Rat10: 0.35

DATA

\begin{tabular}{lccc}
\hline & \multicolumn{4}{c}{ Groups } \\
\hline \multirow{2}{*}{ 1. At $25 \%$ R.H. } & 2. At $50 \%$ R.H. & 3. At $75 \%$ R.H. \\
\hline Total & 3051 & 2542 & 1356 \\
\hline Mean & 2967 & 2458 & 1272 \\
\hline & 6018 & 5000 & 2628 \\
\hline & 3009 & 2500 & 1314 \\
\hline$C_{1}=$ Contrast: $25 \%$ R.H. Vs & $50 \%$ R.H. & \\
& $C_{2}=$ Contrast: $50 \%$ R.H. Vs & $75 \%$ R.H.
\end{tabular}

ANALYSIS OF VARIANCE TABLE

\begin{tabular}{lcrrr}
\hline \multicolumn{1}{c}{ Source } & $\begin{array}{c}\text { Deg. of } \\
\text { Freedom }\end{array}$ & $\begin{array}{c}\text { Sum of } \\
\text { Squares }\end{array}$ & $\begin{array}{c}\text { Mean } \\
\text { Squares }\end{array}$ & F-Rat10 \\
\hline Among groups & 2 & 3025801.3 & 1512900.6 & 428.8 \\
Contrast C 1 & 1 & 259081.0 & 259081.0 & 73.4 \\
Contrast C 2 & 1 & 1406596.0 & 1406596.0 & 398.7 \\
Within Groups & 3 & 10584.0 & 3528.0 & \\
\hline Total & 5 & 3036385.3 & & \\
\hline
\end{tabular}
$F_{.01,2,3}=30.8$
$F_{01,1,3}=34.1$ 
TABLE 26 SHRINKAGES USING LIGNOSULFONATE

Water Cement Rat10: 0.35

DATA

\begin{tabular}{lccc}
\hline & \multicolumn{4}{c}{ Groups } \\
\hline & 1. At $25 \%$ R.H. & 2. At $50 \%$ R.H. & 3. At 75\% R.H. \\
\hline Observat1ons & 3644 & 3221 & 2543 \\
& 3560 & 3136 & 2458 \\
\hline Total & 7204 & 6357 & 5001 \\
\hline Mean & 3602 & 3178.5 & 2500.5 \\
\hline
\end{tabular}

$C_{1}=$ Contrast: $25 \%$ R.H. V8 $50 \%$ R.H.

$C_{2}=$ Contrast: $50 \%$ R.H. Vs $75 \%$ R.H.

ANALYSIS OF VARIANCE TABLE

\begin{tabular}{|c|c|c|c|c|}
\hline Source & $\begin{array}{l}\text { Deg. of } \\
\text { Freedom }\end{array}$ & $\begin{array}{r}\text { Sum of } \\
\text { Squares }\end{array}$ & $\begin{array}{c}\text { Mean } \\
\text { Squares }\end{array}$ & F-Rat 10 \\
\hline Among groups & 2 & 1234892.3 & 617446.1 & 172.2 \\
\hline Contrast $C_{1}$ & 1 & 179352.2 & 179352.2 & 50.0 \\
\hline Contrast $\mathrm{C}_{2}$ & 1 & 459684.0 & 459684.0 & 128.2 \\
\hline Within Groups & 3 & 10753.0 & 3584.3 & \\
\hline Total & 4 & 1245645.3 & & \\
\hline
\end{tabular}


TABLE 27 SHRINKAGES USING CARBOHYDRATE

Water Cement Rat10: 0.35

DATA

Group s

\begin{tabular}{lccc}
\hline & 1. At 25\% R.H. & 2. At $50 \%$ R.H. & 3. At $75 \%$ R.H. \\
\hline & 4916 & 3644 & 2204 \\
Observations & 4746 & 3644 & 2373 \\
\hline Total & 9662 & 7288 & 4577 \\
\hline Mean & 4831 & 3644 & 2288.5 \\
\hline
\end{tabular}

$C_{1}$ : Contrast: $25 \%$ R.H. Vs $50 \%$ R.H.

$\mathrm{C}_{2}=$ Contrast: $50 \%$ R.H. Vs $75 \%$ R.H.

ANALYSIS OF VARIANCE TABLE

\begin{tabular}{lcrrr}
\hline Source & $\begin{array}{c}\text { Deg. of } \\
\text { Freedom }\end{array}$ & $\begin{array}{r}\text { Sum of } \\
\text { Squares }\end{array}$ & $\begin{array}{c}\text { Mean } \\
\text { Squares }\end{array}$ & F-Ratio \\
\hline Among groups & $2^{\prime}$ & 6473770.3 & 3236885.1 & 337.9 \\
Contrast C 1 & 1 & 1408979.0 & 1408979.0 & 147.1 \\
Contrast C 2 & 1 & 1837380.2 & 1837380.2 & 191.8 \\
W1thin Groups & 3 & 28730.5 & 9576.8 & \\
\hline Total & 5 & 6502500.0 & & \\
\hline
\end{tabular}
$\mathrm{F}_{.01,2,3}=30.8$
$F_{.01,1,3}=34.1$ 
TABLE 28 SHRINKAGES USING HYDROXYCARBOXYLIC ACID

Water Cement Rat10: 0.35

DATA

Groups

1. At $25 \%$ R.H.

2. At $50 \%$ R.H.

3. At $75 \%$ R.H.

\begin{tabular}{lccc}
\hline Observations & 6187 & 4746 & 3136 \\
\hline Total & 5848 & 4831 & 2967 \\
\hline Mean & 12035.0 & 9577 & 6103 \\
\hline
\end{tabular}

$C_{1}=$ Contrast: $25 \%$ R.H. VB $50 \%$ R.H.

$C_{2}=$ Contrast: $50 \%$ R.H. VB $75 \%$ R.H.

ANALYSIS OF VARIANCE TABLE

\begin{tabular}{|c|c|c|c|c|}
\hline Source & $\begin{array}{l}\text { Deg. of } \\
\text { Freedom }\end{array}$ & $\begin{array}{r}\text { Sum of } \\
\text { Squares }\end{array}$ & $\begin{array}{c}\text { Mean } \\
\text { Squares }\end{array}$ & F-Rat10 \\
\hline Among groups & 2 & 8883177.3 & 4441588.6 & 176.8 \\
\hline Contrast $C_{1}$ & 1 & 1510441.0 & 1510441.0 & 60.1 \\
\hline Contrast $\mathrm{C}_{2}$ & 1 & 3017169.0 & 3017169.0 & 120.1 \\
\hline Within Groups & 3 & 75353.5 & 14117.8 & \\
\hline Total & 5 & 8958530.8 & & \\
\hline${ }^{F} .01,2,3$ & & & $\mathrm{~F}_{01,1,3}=$ & \\
\hline
\end{tabular}


TABLE 29 COMPARISON OF SLOPES AT 25\% R.H.

Water Cement Rat10: .35 Relative Humid1ty: $25 \%$

DATA

\begin{tabular}{lcccc}
\hline & \multicolumn{4}{c}{ Groups } \\
\hline & $\begin{array}{c}1 \\
\text { Plain } \\
\text { Paste }\end{array}$ & $\begin{array}{c}\text { Ligno- } \\
\text { 8ulfonate }\end{array}$ & $\begin{array}{c}\text { Carbo } \\
\text { hydrate }\end{array}$ & $\begin{array}{c}4 \\
\text { Hydroxy } \\
\text { Corboxylic Ac1d }\end{array}$ \\
\hline \multirow{2}{*}{ Observations } & 822.1 & 709.9 & 944.3 & 1021.6 \\
& 889.8 & 723.8 & 922.5 & 959.5 \\
\hline Total & 1711.9 & 1433.7 & 1866.8 & 1981.1 \\
\hline Mean & 855.9 & 716.8 & 933.4 & 990.5 \\
\hline
\end{tabular}

$C_{1}=$ Contrast: Plain Paste V8 Lignosulfonate

$\mathrm{C}_{2}=$ Contrast: Plain Paste Vs Carbohydrate

$C_{3}=$ Contrast: Plain Paste Vs Hydroxy Carboxylic acid

ANALYSIS OF VARIANCE TABLE

\begin{tabular}{|c|c|c|c|c|}
\hline Source & $\begin{array}{l}\text { Deg. of } \\
\text { Freedom }\end{array}$ & $\begin{array}{l}\text { Sum of } \\
\text { Squares }\end{array}$ & $\begin{array}{c}\text { Mean } \\
\text { Squares }\end{array}$ & F-Ratio \\
\hline Among Groups & 3 & 84253.8 & 28084.6 & 24.67 \\
\hline Contrast $C_{1}$ & $I$ & 19336.7 & 19336.7 & 16.9 \\
\hline Contrast $C_{2}$ & 1 & 6002.9 & 6002.9 & 5.27 \\
\hline Contrast $\mathrm{C}_{3}$ & 1 & 18120.8 & 18120.8 & 15.9 \\
\hline Within Groups & 4 & 4553.0 & 1138.2 & \\
\hline Total Corrected & 7 & 88806.8 & & \\
\hline
\end{tabular}


TABLE 30 COMPARISON OF SLOPES AT 50\% R.H.

Water Cement Rat10: 0.35 Relat1ve Hun1d1ty: 50\%

DATA

\begin{tabular}{lcccc}
\hline & \multicolumn{4}{c}{ Groups } \\
\hline & $\begin{array}{c}1 \\
\text { Plain } \\
\text { Paste }\end{array}$ & $\begin{array}{c}2 \\
\text { Ligno- } \\
\text { sulfonate }\end{array}$ & $\begin{array}{c}\text { Carbo- } \\
\text { hydrate }\end{array}$ & $\begin{array}{c}4 \\
\text { Hydroxy } \\
\text { Carboxyl1c Ac1d }\end{array}$ \\
\hline \multirow{2}{*}{ Observat1ons } & 711.1 & 547.1 & 468.6 & 725.7 \\
& 745.7 & 527.3 & 490.9 & 750.6 \\
\hline Total & 1456.8 & 1074.5 & 959.5 & 1476.3 \\
\hline Mean & 728.4 & 537.2 & 479.7 & 738.1 \\
\hline
\end{tabular}

$C_{1}=$ Contrast: Plain Paste Vs L1gnosulfonate

$\mathrm{C}_{2}$ - Contrast: Plain Paste Vs Carbohydrate

$\mathrm{C}_{3}$ - Contrast: Plain Paste $\mathrm{Vs}$ Hydroxy Carboxyl1c ac1d

ANALYSIS OF VARIANCE TABLE

\begin{tabular}{|c|c|c|c|c|}
\hline Source & $\begin{array}{l}\text { Deg. of } \\
\text { Freedom }\end{array}$ & $\begin{array}{l}\text { Sum of } \\
\text { Squares }\end{array}$ & $\begin{array}{c}\text { Mean } \\
\text { Squares }\end{array}$ & F-Rat 10 \\
\hline Among Groups & 3 & 104428.2 & 34809.4 & 103.0 \\
\hline Contrast $C_{1}$ & 1 & 36535.6 & 36535.6 & 108.1 \\
\hline Contrast $C_{2}$ & 1 & 61804.3 & 61804.3 & 182.9 \\
\hline Contrast $\mathrm{C}_{3}$ & 1 & 95.3 & 95.3 & 0.218 \\
\hline Within Groups & 4 & 1351.1 & 337.7 & \\
\hline Total Corrected & 7 & 105779.4 & & \\
\hline
\end{tabular}


TABLE 31 COMPARISON OF SLOPES AT $75 \%$ R.H.

Water Cement Rat1o: $0.35 \quad$ Relative Humidity: $75 \%$

DATA

\begin{tabular}{ccccc}
\hline & \multicolumn{4}{c}{ Groups } \\
& $\begin{array}{c}1 \\
\text { Plain } \\
\text { Paste }\end{array}$ & $\begin{array}{c}2 \\
\text { Ligno- } \\
\text { gulfonate }\end{array}$ & $\begin{array}{c}\text { Carbo- } \\
\text { hydrate }\end{array}$ & $\begin{array}{c}\text { Carboxyl1c Ac1d } \\
\text { Hydroxy }\end{array}$ \\
\hline Observations & 339.1 & 429.1 & 303.5 & 400.3 \\
\hline Total & 318.4 & 467.8 & 315.9 & 361.1 \\
\hline Mean & 657.5 & 896.9 & 619.4 & 761.4 \\
\hline
\end{tabular}

$C_{1}=$ Contrast: Plain Paste Vs Lignosulfonate

$C_{2}=$ Contrast: Plain Paste Vs Carbohydrate

$C_{3}=$ Contrast: Plain Paste Vs Hydroxy Carboxylic acld

ANALYSIS OF VARIANCE TABLE

\begin{tabular}{|c|c|c|c|c|}
\hline Source & & $\begin{array}{l}\text { Sum of } \\
\text { Squares }\end{array}$ & $\begin{array}{c}\text { Mean } \\
\text { Squares }\end{array}$ & F-Rat 1o \\
\hline Among Groups & 3 & 2313.4 & 7710.4 & 17.1 \\
\hline Contrast $C_{1}$ & 1 & 14321.1 & 14321.1 & 31.7 \\
\hline Contrast $\mathrm{C}_{2}$ & 1 & 363.8 & 363.8 & 0.8 \\
\hline Contrast $\mathrm{C}_{3}$ & 1 & 2696.6 & 2696.6 & 5.9 \\
\hline W1thin Groups & 4 & 1804.9 & 451.2 & \\
\hline Total Corrected & 7 & 24936.3 & & \\
\hline
\end{tabular}


TABLE 32 SLOPES FOR PLAIN PASTE

Water Cement Rat10: .35

DATA

\section{Group 8}

\begin{tabular}{|c|c|c|c|}
\hline & 1. At $25 \%$ R.H. & 2. At $50 \%$ R.H. & 3. At $75 \%$ R.H. \\
\hline \multirow{2}{*}{ Observations } & 822.1 & 711.1 & 339.1 \\
\hline & 889.8 & 745.7 & 318.4 \\
\hline Total & 1711.9 & 1456.8 & 657.6 \\
\hline Mean & 855.9 & 728.4 & 328.8 \\
\hline
\end{tabular}

$$
\begin{aligned}
& C_{1}=\text { Contrast: } 25 \% \text { R.H. Vs } 50 \% \text { R.H. } \\
& C_{2}=\text { Contrast: } 50 \% \text { R.H. Vs } 75 \% \text { R.H. }
\end{aligned}
$$

\begin{tabular}{|c|c|c|c|c|}
\hline Source & $\begin{array}{l}\text { Deg. of } \\
\text { Freedom }\end{array}$ & $\begin{array}{l}\text { Sum of } \\
\text { Squares }\end{array}$ & $\begin{array}{c}\text { Mean } \\
\text { Squares }\end{array}$ & F-Rat 10 \\
\hline Among groups & 2 & 302564.4 & 151282.2 & 146.2 \\
\hline Contrast $C_{1}$ & 1 & 16269.0 & 16269.0 & 15.7 \\
\hline Contrast $\mathrm{C}_{2}$ & 1 & 160830.3 & 160830.3 & 155.4 \\
\hline W1thin Groups & 3 & 3104.2 & 1034.7 & \\
\hline Total & 5 & 305668.7 & & \\
\hline
\end{tabular}

INALYSIS OF VARIANCE TABLE 
TABLE 33 SLOPES USING LIGNOSULFONATE

Water Cement Ratio: 0.35

DATA

Groups

\begin{tabular}{lccc}
\hline & 1. At $25 \%$ R.H. & 2. At $50 \%$ R.H. & 3. At $75 \%$ R.H. \\
\hline \multirow{2}{*}{ Observations } & 709.9 & 527.4 & 429.2 \\
& 723.8 & 547.1 & 467.8 \\
\hline Total & 1433.8 & 1074.5 & 896.9 \\
\hline Mean & 716.9 & 537.2 & 448.4 \\
\hline
\end{tabular}

$C_{1}=$ Contrast: $25 \%$ R.H. Vs $50 \%$ R.H.

$C_{2}=$ Contrast: $50 \%$ R.H. Vs $75 \%$ R.H.

ANALYSIS OF VARIANCE TABLE

\begin{tabular}{|c|c|c|c|c|}
\hline Source & $\begin{array}{l}\text { Deg. of } \\
\text { Freedom }\end{array}$ & $\begin{array}{l}\text { Sum of } \\
\text { Squares }\end{array}$ & $\begin{array}{c}\text { Mean } \\
\text { Squares }\end{array}$ & F-Ratio \\
\hline Among Groups & 2 & 74804.3 & 37402.2 & 108.4 \\
\hline Contrast $C_{1}$ & 1 & 32268.3 & 32268.3 & 93.5 \\
\hline Contrast $\mathrm{C}_{2}$ & 1 & 7884.4 & 7884.4 & 22.8 \\
\hline Within Groups & 3 & 1034.9 & 344.9 & \\
\hline Total & 5 & 75839.3 & & \\
\hline
\end{tabular}




\section{TABLE 34 SLOPES USING CARBOHYDRATE}

Water Cement Rat10: 0.35

DATA

\begin{tabular}{lccc}
\hline \multicolumn{4}{c}{ Groups } \\
\hline & 1. At $25 \%$ R.H. & 2. At $50 \%$ R.H. & 3. At $75 \%$ R.H. \\
\hline \multirow{2}{*}{ Observat1ons } & 944.3 & 468.6 & 303.5 \\
& 922.5 & 490.9 & 315.9 \\
\hline Tota1 & 1866.8 & 959.6 & 619.4 \\
\hline Mean & 933.4 & 479.8 & 309.7 \\
\hline
\end{tabular}

$C_{1}=$ Contrast: $25 \%$ R.H. Vs $50 \%$ R.H.

$\mathrm{C}_{2}$ = Contrast: $50 \%$ R.H. Vs $75 \%$ R.H.

ANALYSIS OF VARIANCE TABLE

\begin{tabular}{lcccc}
\hline Source & $\begin{array}{c}\text { Deg. of } \\
\text { Freedom }\end{array}$ & $\begin{array}{l}\text { Sum of } \\
\text { Squares }\end{array}$ & $\begin{array}{c}\text { Mean } \\
\text { Squares }\end{array}$ & F-Rat1o \\
\hline Anong Groups & 2 & 415815.9 & 207907.9 & 1109.4 \\
Contrast C 1 & 1 & 205783.3 & 205783.3 & 1098.4 \\
Contrast C 2 & 1 & 28926.1 & 28926.1 & 154.4 \\
Within Groups & 3 & 562.2 & 187.4 & \\
& & & & \\
\hline Total & 5 & 416378.1 & & F $01,1,3=34.1$
\end{tabular}


TABLE 35 SLOPES USING HYDROXYCARBOXYLIC ACID

Water Cement Rat1o 0.35

DATA

\begin{tabular}{lccc}
\hline \multicolumn{4}{c}{ Groups } \\
\hline & 1. At $25 \%$ R.H. & 2. At $50 \%$ R.H. & 3. At $75 \%$ R.H. \\
\hline Observations & 1021.6 & 725.7 & 400.3 \\
& 959.5 & 750.6 & 361.1 \\
\hline Total & 1981.1 & 1476.3 & 761.4 \\
\hline Mean & 990.6 & 738.2 & 380.7 \\
\hline
\end{tabular}

$C_{1}=$ Contrast: $25 \%$ R.H. V8 $50 \%$ R.H.

$\mathrm{C}_{2}=$ Contrast: $50 \%$ R.H. Vs $75 \%$ R.H.

ANALYSIS OF VARIANCE TABLE

\begin{tabular}{|c|c|c|c|c|}
\hline Source & $\begin{array}{l}\text { Deg. of } \\
\text { Freedom }\end{array}$ & $\begin{array}{l}\text { Sum of } \\
\text { Squares }\end{array}$ & $\begin{array}{c}\text { Mean } \\
\text { Squares }\end{array}$ & F-Ratio \\
\hline Among Groups & 2 & 375583.1 & 187791.5 & 187.3 \\
\hline Contrast $\mathrm{C}_{1}$ & 1 & 63703.9 & 63703.9 & 63.5 \\
\hline Contrast $C_{2}$ & 1 & 127765.8 & 127765.8 & 127.4 \\
\hline W1thin Groups & 3 & 3007.5 & 1002.5 & \\
\hline Total & 5 & 378590.6 & & \\
\hline
\end{tabular}


TABLE 36 NON-EVAPORABLE WATER DETERMINATION

\begin{tabular}{lcccc}
\hline Contalner Nos. & 1 & 2 & 3 & 4 \\
$\begin{array}{l}\text { Welght of sample } \\
\begin{array}{l}\text { Weight of non-evaporable } \\
\text { water }\left(W_{\mathrm{n}}\right)\end{array}\end{array}$ & 0.4776 & 0.4914 & 0.3530 & 0.3701 \\
$\begin{array}{l}\text { Welght of dry sample } \\
W_{\mathrm{n}} \text { /wt. of dry sample }\end{array}$ & 0.0255 & 0.0244 & 0.0246 & 0.0249 \\
\hline
\end{tabular}

Note:

1) Weights in $g$.

2) Container Nos, 1 and 2 contains sample from specimen kept in laboratory condition.

3) Container Nos. 3 and 4 contains sample from specimen kept in controlled 50 percent relative humidity.

4) Samples are vacuum oven dried for about 36 hours.

5) Non-evaporable water from PEN FIELD TEST. 
TABLE 37 SHRINKAGE OF PLAIN PASTE BY PASSING LABORATORY AIR DIRECTLY OVER THE SPECIMEN

Relative humidity varled from $59 \%$ when experiment started to $51 \%$ at the end of the experiment. Temperature is about $24^{\circ} \mathrm{C}$

\begin{tabular}{cccc}
$\begin{array}{c}\text { Time } \\
\text { (hours) }\end{array}$ & $\begin{array}{c}\text { Voltmeter Reading } \\
\text { (volts) }\end{array}$ & $\begin{array}{c}\text { Change in Probe } \\
\text { Gap (Inches) }\end{array}$ & $\begin{array}{c}\text { Linear Shrinkage } \\
\text { (m11lionths) }\end{array}$ \\
\hline 0 & 2.260 & - & -- \\
1 & 2.310 & 0.0010 & 170 \\
2 & 2.470 & 0.0030 & 509 \\
3 & 2.740 & 0.0075 & 1272 \\
4 & 3.100 & 0.0120 & 2034 \\
6 & 3.240 & 0.0140 & 2373 \\
\hline
\end{tabular}

SAMPLE OF CALCULATION:

Change in probe gap at one hour = (probe gap, at one hourprobe gap at zero hour) from callbration curve.

1.e. change in probe gap at one hour $=0.0510-0.0500$ $=00.001$ Inch

$$
\begin{aligned}
\text { Linear shrinkage in millionths } & =\frac{\text { Change in probe gap }}{5.9 \times 10^{6}} \\
& =\frac{0.001}{5.9 \times 10^{6}} \\
& =170
\end{aligned}
$$



